\title{
Significance of Brettanomyces and Dekkera during Winemaking: A Synoptic Review
}

\author{
A. Oelofse ${ }^{1}$, I.S. Pretorius ${ }^{2}$ and M. du Toit ${ }^{*}$
}

(1) Institute for Wine Biotechnology, Stellenbosch University, Private Bag X1, Matieland (Stellenbosch), 7602, South Africa

(2) The Australian Wine Research Institute, PO Box 197, Glen Osmond (Adelaide), SA 5064, Australia

Submitted for publication: August 2008

Accepted for publication: September 2008

Key words: Brettanomyces; Dekkera; red wine; volatile phenols; control; spoilage; isolation; identification

\begin{abstract}
Wine comprises a complex microbial ecology of opportunistic microorganisms, some of which could potentially induce spoilage and result in consequent economic losses under uncontrolled conditions. Yeasts of the genus Brettanomyces, or its teleomorph Dekkera, have been indicated to affect the chemical composition of the must and wine by producing various metabolites that are detrimental to the organoleptic properties of the final product. These yeasts can persist throughout the harsh winemaking process and have in recent years become a major oenological concern worldwide. This literature review summarises the main research focus areas on yeasts of the genera Brettanomyces and Dekkera in wine. Specific attention is given to the spoilage compounds produced, the methods of detection and isolation from the winemaking environment and the factors for controlling and managing Brettanomyces spoilage.
\end{abstract}

Winemaking comprises a diverse set of factors that play a crucial role during the transformation of grapes to wine. The most important factors generally considered by winemakers include vineyard management, grape quality, winemaking practices and commercial yeast selection. However, the microbiology behind the wine should also be considered because this is one of the parameters often neglected as a quality control constraint. Wine microbiology entails a complex interaction of a variety of microorganisms that play an essential role on the outcome of the final product and, if the microbiology of wine is disregarded, there will simply be no wine.

The involvement of microorganisms in the fermentation of alcoholic beverages has been a subject of interest for centuries. As early as the mid-1800s, Louis Pasteur observed the conversion of grape juice into wine by the action of yeast and noticed the presence of bacteria that were capable of causing wine spoilage (Drysdale \& Fleet, 1988). Since then the microbiology of wine has been the topic of many investigations and a large diversity of microorganisms that are present during the winemaking process have been identified (Fugelsang, 1997; Loureiro, 2000).

Apart from the principal wine yeast Saccharomyces cerevisiae, different genera and species of bacteria and non-Saccharomyces yeasts have been identified. These microorganisms form a natural part of the active biomass involved in the winemaking process as they are found on grapes, in the must and wine and can therefore contribute to the organoleptic properties of the final product (Heard \& Fleet, 1988; Fleet \& Heard, 1993; Lambrechts \& Pretorius, 2000). The contributions are, however, not always positive with regard to the wine's flavour because microbial activity often results in wine spoilage.

Wine spoilage is a serious problem for the wine industry because it renders the products unacceptable and can lead to large economic losses. For this purpose, research is targeted towards the microorganisms that are responsible for spoilage during the winemaking process. The typical focus areas include: methods of detection, identification and characterisation of spoilage microorganisms; the monitoring and control of spoilage compounds; and fundamental investigations to gain more knowledge on the metabolism and activities of spoilage microorganisms.

One of the controversial yeasts that has gained increasing attention in recent years, specifically as it is associated with wine spoilage, belongs to the genera Brettanomyces and Dekkera wellknown for the production of ethyl phenols. This review presents a summary of some of the above-mentioned major scientific focus areas about the yeasts Brettanomyces and Dekkera during winemaking.

\section{BRETTANOMYCES AND DEKKERA DURING WINEMAKING}

\section{History of Brettanomyces}

The first reference to the genus Brettanomyces dates back to 1904 when N.H. Claussen isolated a yeast from a slow secondary fermentation of an old English stock beer (Gilliland, 1961). The flavours produced by this yeast became characteristic of the British beers of that time and so the name 'Brettanomyces' was derived from 'British brewing fungus'. It was not until the 1940s, when M.T.J. Custers performed the first systematic study on Brettanomyces yeast, that Brettanomyces was associated with wine (Custers, 1940). Although this study included 17 strains, of which most were isolated from beer, one strain originated from a French wine (Krumbholz \& Tauschanoff, 1933).

\section{Different species in wine}

The taxonomy of the genus Brettanomyces has seen numerous reclassifications over the years from the handful of species that were initially identified. Originally, these species included Brettanomyces bruxellensis, Brettanomyces lambicus, Brettanomyces clausenii, Brettanomyces anomalus and Brettanomyces intermedius, which reproduced asexually by means of budding (Custers, 1940;

*Corresponding author: mdt@sun.ac.za

Acknowledgements: Thalès (member of Chène \& Cie, France) for the Brettanomyces project support. 
Van der Walt \& Van Kerken, 1958). The genus Dekkera was introduced to the taxonomy in 1964 after the production of ascospores (sporulating-form) was observed (Van der Walt, 1984). Currently, the five species jointly belonging to the genera Brettanomyces and Dekkera are: Brettanomyces custersianus, Brettanomyces naardenensis, Brettanomyces nanus, B. anomalus and B. bruxellensis (Kurtzman \& Fell, 2000; Cocolin et al., 2004). Teleomorphs (perfect state) are known for the last two species, Dekkera anomala and Dekkera bruxellensis, respectively (Kurtzman \& Fell, 2000). The details regarding the morphological, biochemical and physiological characteristics of these species are well described in recent classification manuals (Barnett et al., 2000; Boekhout et al., 2002; Kurtzman \& Fell, 2000). From the five species currently known, the species primarily associated with winemaking is $B$. bruxellensis (D. bruxellensis) (Egli \& HenickKling, 2001; Stender et al., 2001; Cocolin et al., 2004), although $B$. anomalus (D. anomala) and B. custersianus isolations from must fermentations have been reported in two instances (Querol et al., 1990; Esteve-Zarzoso et al., 2001). With advances in DNAbased methods, recent wine-related investigations often include $D$. anomala along with the predominant species D. bruxellensis as conventional methods had showed difficulty in differentiating between these two species (Loureiro \& Malfeito-Ferreira, 2006). Although current taxonomical classifications suggest that Dekkera should be used in reference with the species bruxellensis and anomala (Boekhout et al., 1994), many discrepancies exist and some authors frequently prefer using the technically incorrect naming of $B$. bruxellensis and B. anomalus when referring to these yeasts in a winemaking context. This is largely attributed to the fact that the sexual or sporulating form, Dekkera, is yet to be found in wine.

Some authors have made the point that the separation of Brettanomyces and Dekkera in the context of wine is meaningless because current molecular DNA techniques reveal no distinction between the anamorph and teleomorph forms (Loureiro \& Malfeito-Ferreira, 2006). This might explain why it is not uncommon to see the use of 'Brettanomyces/Dekkera spp.' in wine research. In this review, the same context will be used in which the original authors used the naming in their publications. This can either be B. bruxellensis or D. bruxellensis.

\section{Occurrence and distribution during winemaking}

Brettanomyces/Dekkera spp. are ubiquitously distributed in nature and their occurrence and spoilage activities have been well summarised by Loureiro and Malfeito-Ferreira (2006). The majority of reports associate Brettanomyces/Dekkera spp. with fermented food products ranging from cheeses and fermented milk to various alcoholic beverages including wine, beer, cider, kombucha (fungus-tea) and tequila (Davenport, 1976; Kumara \& Verachtert, 1991; Lachance, 1995; Kosse et al., 1997; Licker et al., 1998; Gadaga et al., 2002; Teoh et al., 2004; Loureiro \& MalfeitoFerreira, 2006). Less frequent reports of their isolations from other sources (bees, fruit-flies, olives and carbonated drinks) are also available (Van der Walt \& Van Kerken, 1958; Phaff et al., 1978; Deák \& Beuchat, 1995; Kotzekidou et al., 1997). Brettanomyces/ Dekkera spp. have been and still are isolated from wines and wineries all around the world, predominantly from red wines. These yeasts are less frequently isolated from white wines (Licker et al., 1998; Dias et al., 2003b) although their loss of viability and the consequent non-existence of ethylphenol levels in white wines is largely ascribed to the efficiency of sulfur dioxide $\left(\mathrm{SO}_{2}\right)$ at lower $\mathrm{pH}$ conditions (Loureiro \& Malfeito-Ferreira, 2006). Hence, the focus of the research on these yeasts has primarily fallen on their occurrence in red wine.

The winemaking process hosts multiple sources where Brettanomyces/Dekkera spp. can survive and numerous debates about the initial source and dispersion of these yeasts have occurred (Licker et al., 1998). The vineyard provides many sources, including the soil, rootlets, bark, leaves and grapes. Davenport (1976) investigated all of these but could not isolate any Brettanomyces spp. In 1987, Guerzoni and Marchetti reported their isolation from grapes damaged by sour rot. This agrees with recent knowledge suggesting a connection between Brettanomyces/Dekkera and damaged grapes (Botrytis-affected) (Taillandier, 2007). Surprisingly, only one investigation has been successful in recovering Brettanomyces/Dekkera spp. from grapes (Renouf \& Lonvaud-Funel, 2006) despite the fact that they have been isolated many times from fermenting musts during earlier research (Licker et al., 1998; Pretorius, 2000; Jolly et al., 2003; Prakitchaiwattana et al., 2004; Van de Water, 2004). The poor detection of Brettanomyces/Dekkera spp. on grapes has been speculated to be the result of their low cell numbers amid a diverse microbial ecosystem where other wild yeast and bacterial species dominate. Renouf and Lonvaud-Funel (2006), however, overcame this problem by developing an enrichment medium that enabled them to detect $B$. bruxellensis on grape berries. They were subsequently able to detect this yeast from several vineyards and at different stages of grape berry development.

Following the initial stages of winemaking, Brettanomyces/ Dekkera spp. have been more consistently associated with wine and cellar equipment (Fugelsang, 1998). As their populations are usually minor in the presence of numerous other rapidly fermenting yeasts, their increase in numbers only occurs during more nutritionally favourable conditions that suit their slowgrowing characteristics (Fugelsang et al., 1993). These conditions are created once alcoholic fermentation is completed and traces of residual sugars allow them to proliferate more easily. Malolactic fermentation (MLF) and ageing in used barrels have therefore been recognised as the most critical stages of wine production for Brettanomyces/Dekkera contamination (Chatonnet et al., 1992, 1995; Fugelsang et al., 1993; Licker et al., 1998; Renouf et al., 2006b; Suárez et al., 2007). During MLF, Brettanomyces/Dekkera spp. is presented with conditions of low free sulfur dioxide, low residual sugar concentrations and yeast autolysis with the release of nutrients occurring along with modest microbial competition. The main characteristics of oak barrels (new and old) that are beneficial to Brettanomyces/Dekkera growth are the porous microstructure, which allows the influx of small amounts of oxygen (Swaffield \& Scott, 1995; Loureiro \& Malfeito-Ferreira, 2006) and the presence of cellobiose that can serve as sugar resource (Boulton et al., 1996). In addition, difficulty of sanitation (old barrels) is favourable to established Brettanomyces/Dekkera populations and promotes contamination of wine (Pollnitz et al., 2000; Yap et al., 2007). When MLF is performed in barrels these characteristics can aid the growth of Brettanomyces/Dekkera. That these yeasts have also been recovered from wines in concrete or stainless steel tanks is more likely due to other reasons of survival 
than those pertaining in barrels (Chatonnet et al., 1992; Rodrigues et al., 2001). Furthermore, numerous finished and bottled wines have also been known to host Brettanomyces/Dekkera populations. These wines have been linked to prior conditions of long periods of barrel ageing, lower $\mathrm{SO}_{2}$ concentrations and less filtration prior to bottling (Herezstyn, 1986a; Arvik et al., 2002).

Wineries and equipment that have been investigated revealed the presence of Brettanomyces/Dekkera yeasts in winery air samples and on cellar walls, drains, pumps, transfer lines and other pieces of equipment that are difficult to sterilise (Van der Walt, 1984; Alguacil et al.,1998; Fugelsang, 1998; Connel et al., 2002). It is therefore not surprising that wineries are often considered as the primary source of Brettanomyces/Dekkera contamination, as opposed to grapes. However, as its occurrence is often inconsistent, each winery can present a unique situation that requires the determination of the specific origin and route of contamination.

\section{DETECTION AND IDENTIFICATION METHODS}

\section{Isolation media}

The isolation of Brettanomyces/Dekkera spp. from winemaking environments is not easy as they are slow growing and have low occurrence (Fugelsang, 1997). Additionally, it has been described that Brettanomyces/Dekkera yeasts are difficult to recover from materials heavily contaminated with other microorganisms (Van der Walt \& Van Kerken, 1960). For this purpose, several authors have investigated different possibilities of selective media by altering the main constituents and carbon sources (Heard \& Fleet, 1986). The earlier media for Brettanomyces isolation included maltose and sucrose as carbon sources and it was reported that the use of sorbate, ethanol and cycloheximide as antimicrobials was not satisfactory (Van der Walt \& Van Kerken, 1960; Wright \& Parle, 1974). More recent studies included glycerol and trehalose with sucrose as carbon sources with a wider range of antimicrobial agents (gentamicin, oxytetracycline, cycloheximide and sorbic acid) to suppress the growth of unwanted yeasts and bacteria (Chatonnet et al., 1992; Fugelsang et al., 1997; Alguacil et al., 1998). Furthermore, vitamins such as thiamine and biotin have also been suggested as these can be beneficial to the growth of Brettanomyces/Dekkera, although some authors do not regard this as necessary (Fugelsang et al., 1997; Loureiro \& Malfeito-Ferreira, 2006). The development of a selective or differential medium specifically for the isolation of Brettanomyces/Dekkera spp. was presented by Rodrigues et al. (2001). This medium, named DBDM (Dekkera/Brettanomyces Differential Medium), was reported as being able to recover less than $1 \%$ of the target yeasts from a total microbial population in combination with the Most Probable Number (MPN) technique. Along with yeast nitrogen base (YNB) this medium contained two antimicrobial agents (ethanol and cycloheximide), a $\mathrm{pH}$ indicator (bromocresol green) to indicate media acidification and a substrate ( $p$-coumaric acid). The latter compound was included as its degradation results in a distinct phenolic off-odour that can be indicative of Brettanomyces/ Dekkera activity. For a more comprehensive list of media that have been tested for the detection of Brettanomyces/Dekkera spp. refer to Rodrigues et al. (2001).

The development of a selective liquid medium that enabled the detection of Brettanomyces/Dekkera spp. followed the works of Rodrigues et al. (2001). This WLN (Wallerstein Laboratory
Nutrient)-based medium was aimed at the development of a simple detection system for Brettanomyces/Dekkera yeast that could be used on a routine basis in the wine industry (Couto et al., 2005a). Liquid media have been described as having a resuscitation function that could be beneficial for the recovery of some microorganisms (e.g. yeast) while reducing mould growth (Loureiro \& Malfeito-Ferreira, 2006).

As mentioned before, the prevalence of Brettanomyces/Dekkera spp. on grapes has been remarkably low and the lack of recoveries has been ascribed to the short-comings of optimal isolation media and poor detection limits. Renouf and Lonvaud-Funel (2006) proposed the use of an enrichment medium to overcome this problem and obtained good success with the detection of $D$. bruxellensis on the surface of grape berries. The use of enrichment steps has previously proven very useful for the detection of scarcely represented $S$. cerevisiae and $S$. paradoxus on grapes (Van der Westhuizen et al., 2000; Redzepovic et al., 2002) and should definitely be considered at times when the presence of Brettanomyces/Dekkera is uncertain. It is also necessary to emphasize the importance of incubation time while performing detection and isolation of Brettanomyces/Dekkera spp. from the winemaking environment. Their low growth rate and fastidious nutritional requirements demand incubation times of up to two weeks (Rodrigues et al., 2001) making the general incubation periods (three to six days at $25-30^{\circ} \mathrm{C}$ ) used for other yeasts inadequate for routine microbiological screenings.

Direct methods of enumeration by plating on selective growth media can be inaccurate resulting from the possible viable but non-culturable (VBNC) state of microorganisms. Cells in the VBNC state are metabolically active but unable to undergo cellular division for growth in liquid or on agar and are therefore non-culturable (Oliver, 1993). Moreover, evolution to a VBNC state is related to the intensity of the stress (Oliver et al., 1995) and there are hypotheses currently about whether $\mathrm{SO}_{2}$ and ethanol could induce this state amongst Brettanomyces/Dekkera spp. populations in wine (Millet \& Lonvaud-Funel, 2000; Arvik et al., 2005; Du Toit et al., 2005). This is especially important for Brettanomyces/Dekkera spp. as we have found instances where wines contained objectionable levels of ethyl phenols but yielded no culturable cells.

\section{DNA-based identification techniques}

As discussed in the previous section, the conventional identification methods for Brettanomyces/Dekkera spp. are insufficient, especially during the winemaking process where a period of a week is crucial. The low relative occurrence, prolonged incubation times and variable identification results often obtained due to their mixed morphological features (Smith, 2002) prompted development of more rapid and reliable identification techniques of these spoilage yeasts. Therefore recent years have seen the development of several molecular DNA-based techniques (Loureiro \& Querol, 1999).

Stender et al. (2001) developed a technique that does not require DNA extraction and utilises microscopic visualisation of fluorescent Brettanomyces/Dekkera cells after in situ hybridisation of species-specific PNA (peptide nucleic acid) probes to the $26 \mathrm{~S}$ ribosomal RNA (RNA-FISH hybridisation). The authors have assigned a high specificity to this method which uses pelleted D. bruxellensis cells from a centrifuged wine. Considering the difficulties encountered with microscopic identification of cell 
morphologies this method can be very useful. A similar study described the use of FISH probes on sequence regions beyond the D1/D2 domains of the 26S rRNA gene that can successfully detect all of the five currently known Brettanomyces/Dekkera species (D. bruxellensis, D. anomala, B. custersianus, B. nanus and B. naardenensis) (Röder et al., 2007).

Other direct molecular techniques that are fast, sensitive and accurate involve polymerase chain reaction (PCR). Specific sequences spanning the $5.8 \mathrm{~S}$ ribosomal RNA genes and their flanking internal transcribed spacer (ITS1 and 2) regions can be targeted for species identification of Brettanomyces/Dekkera (Esteve-Zarzoso, 1999; Egli \& Henick-Kling, 2001). The 5.8S rRNA and ITS regions have been documented in many studies for yeast identification (White et al., 1990; Guillamon et al., 1998; Esteve-Zarzoso, 1999; Granchi et al., 1999) and can include restriction fragment length polymorphisms (PCR-RFLP) for interspecies discrimination of Brettanomyces/Dekkera yeasts (Esteve-Zarzoso, 1999; Nisiotou \& Gibson, 2005). A nested PCR method comprising two primer sets has been developed for the direct detection of Brettanomyces/Dekkera strains in sherry (Ibeas et al., 1996). This approach is very efficient for identification of $D$. bruxellensis strains from intact yeast cells. Another highly specific PCR (targeting the D1-D2 loop of the 26S rRNA) was developed by Cocolin et al. (2004) that form amplification products only with the species $B$. bruxellensis and B. anomalus. Differentiation between these two species could be achieved after restriction enzyme analysis (DdeI) of the amplified products. The use of denaturing gradient gel electrophoresis (PCR-DGGE) for the characterisation of yeast diversity within wine fermentations has also been indicated to detect Brettanomyces yeasts (Cocolin et al., 2004; Renouf et al., 2006a).

One of the concerns about direct PCR methods is that the sensitivity can depend on the level of contamination (Loureiro \& Malfeito-Ferreira, 2006) and that only a high detection limit $\left(\geq 1 \times 10^{4}\right.$ $\mathrm{cfu} / \mathrm{mL}$ ) may provide a positive result. Several authors have reported that wines could be tainted with a phenolic off-flavour character by Brettanomyces counts below this value (Ibeas et al., 1996; Phister \& Mills, 2003; Cocolin et al., 2004) and therefore PCR detection limits of less than $10^{4} \mathrm{cfu} / \mathrm{mL}$ are required. Phister and Mills (2003) employed real-time PCR and showed detection of D. bruxellensis in wine at levels as low as one to 10 cells $/ \mathrm{mL}$, depending on the dilution factor of the sample. In contrast however, Delaherche et al. (2004) obtained a detection limit of $10^{4} \mathrm{cfu} / \mathrm{mL}$ with real-time PCR and this currently questions the routine use of this technique. A change of the DNA extraction method has greatly improved the detection limit to $10 \mathrm{cfu} / \mathrm{mL}$ by the same authors (personal communication, 2007). Another recent suggestion for achieving detection levels of about $10 \mathrm{cfu} / \mathrm{mL}$ for Brettanomyces/Dekkera yeasts has included the use of a loop-mediated isothermal amplification (LAMP) method (Hayashi et al., 2007).

\section{Genetic diversity and techniques for strain discrimination}

The identification of $D$. bruxellensis as the primary spoilage species during winemaking was soon followed by investigations that focused on determining the genetic diversity amongst this species. Intraspecies identification of Brettanomyces/Dekkera yeasts has not been frequently reported and some of the first techniques that have been described used random amplified polymorphic DNA (RAPDPCR) and amplified fragment length polymorphisms (AFLPs) (de Barros Lopes et al., 1999; Mitrakul et al., 1999). Genetically different strains of $D$. bruxellensis wine isolates were revealed from different vintages and exhibited different chromosomes (three or four) and consequently different chromosomal fingerprints (Mitrakul et al., 1999). It was also shown that the wine strains of $D$. bruxellensis were genetically different from reference strains. Several studies have since been performed that allow for strain identification and they included techniques such as, AFLPs (Bellon et al., 2003; Curtin et al., 2007); PCR fingerprinting with microsatellite primers; intron splice site - PCR (de Barros Lopes et al., 1998); sequencing a portion of the 26S rDNA gene (Conterno et al., 2006); restriction enzyme analysis of mitochondrial DNA and RAPD-PCR with OPA-primers (Martorell et al., 2006); restriction enzyme analysis - pulsed field gel electrophoresis (REA-PFGE) (Miot-Sertier \& Lonvaud-Funel, 2007); and PCR-DGGE (Renouf et al., 2006c). Genetic characterisation studies have relevance in the wine industry because they connect different $D$. bruxellensis strains with geographic origin, vintage year and wine variety (Conterno et al., 2006). Renouf et al. (2006c) found three different chromosomal patterns (after digestion with restriction enzymes) for $D$. bruxellensis isolates from different French wineries, but concluded that the same strains were predominant throughout the winemaking process at the specific wineries. Conterno et al. (2006) found that a total of 47 wine isolates of $B$. bruxellensis could be grouped into six clusters. The same authors also found that physiological traits were highly variable and did not correlate with the groupings from the DNA analysis. Therefore, the genetic diversity that exists among species with related genomes should be further explored to obtain correlations between phenotype (visible and biochemical properties) and genetic composition (Bellon et al., 2003).

In a large study using AFLP analysis for the characterisation of D. bruxellensis isolates from Australian wineries, eight genotypes have been found (Curtin et al., 2007). These eight strain groupings originated from a total of 244 D. bruxellensis isolates from $31 \mathrm{red}$ winemaking regions, in which some strains regularly prevailed. It was also found that the wine strains were highly divergent from the $D$. bruxellensis type strain (Bellon et al., 2003; Curtin et al., 2007).

Future studies on strain identification might give clearer information on the origin of these species during the vinification process. By tracing the routes of Brettanomyces/Dekkera contamination genetically, it might be possible to gather beneficial information for the winemakers which could be considered along with preventative measures (Miot-Sertier \& Lonvaud-Funel, 2007).

\section{WINE SPOILAGE BY BRETTANOMYCES AND DEKKERA SPP.}

Brettanomyces/Dekkera yeasts obtained their significance in wine due to the formation of various spoilage compounds that are detrimental to wine quality. For this reason, most of the investigations performed on these yeast species focussed on their wine spoilage capabilities.

This section will summarise the current knowledge of the main compounds and describe their impact on the organoleptic properties of wine.

\section{Production of volatile phenols}

The production of phenolic off-flavours (POF), specifically volatile phenols, defines the importance of Brettanomyces/Dekkera yeasts during winemaking and has been well documented (Heresztyn, 1986a; Chatonnet et al., 1992, 1995, 1997; Edlin et al., 1995; 
Licker et al., 1998; Suárez et al., 2007). Volatile phenols represent a large family of aromatic compounds of which the vinyland ethylphenols are implicated with Brettanomyces spoilage (Chatonnet et al., 1992). These volatile phenols, especially the ethylphenols, are responsible for off-odours that have been described as 'animal', 'medicinal', 'Elastoplast', 'sweaty leather', 'barnyard', 'spicy' and 'clove-like' and are detrimental to the aroma profile of wines at high concentrations (Chatonnet et al., 1992; 1995; Suárez et al., 2007).

The formation of volatile phenols by Brettanomyces/Dekkera yeast has been shown to be the result of enzymatic transformation of phenolic (hydroxycinnamic) acids present during winemaking (Heresztyn, 1986a; Chatonnet et al., 1992). Hydroxycinnamic acids are naturally present in grape juice and wine and originate from the grapes, where they are generally esterified with tartaric acid or anthocyanin esters (Dugelay et al., 1993). The action of enzymes with cinnamoyl-esterase activity releases these weak acids to their free forms (Gerbaux et al., 2002), in which they can be inhibitory towards the growth of many microorganisms (Stead, 1995; Zaldivar \& Ingram, 1999; Barthelmebs et al., 2001). However, Brettanomyces/Dekkera spp. overcome the toxicity problem by converting these acids into volatile phenols. The formation of volatile phenols by Brettanomyces/Dekkera spp. is shown in Figure 1. The free hydroxycinnamic acid precursors ( $p$-coumaric, ferulic and caffeic acid) are decarboxylated into hydroxystyrenes (4-vinylphenol, 4-vinylguaiacol and 4-vinylcatechol, respectively), and then reduced into their corresponding ethyl-derivative forms (4-ethylphenol, 4-ethylguaiacol and 4-ethylcatechol, respectively) (Heresztyn, 1986a; Chatonnet et al., 1992; Hesford et al., 2004). It is believed that the free available hydroxycinnamic acids can be released by the action of fungal enzymes or by grape juice heating (Gerbaux et al., 2002), although other mechanisms may exist. It is speculated that Brettanomyces/ Dekkera spp. might be able to hydrolyse bound phenolic acids, but there is no scientific proof for this. The bound or the free hydroxycinnamic forms are however not the sole requirement for these yeasts to produce the ethyl-derivatives as $B$. bruxellensis has been shown to produce 4-ethylphenol directly from 4-vinylphenol as substrate (Dias et al., 2003b).

The two enzymes that facilitate the biotransformation of phenolic acids involve a phenolic (cinnamic) acid decarboxylase (PAD) for the formation of the vinyl derivatives and a vinyl phenol reductase (VPR) for the formation of the ethyl derivatives thereafter. The decarboxylation step has been linked to the POF1 (phenolic offflavour) or $P A D 1$ (phenylacrylic acid decarboxylase) gene of $S$. cerevisiae (Clausen et al., 1994). Similar decarboxylase activities exist in numerous bacteria, fungi and yeast species, of which some are present during the winemaking process (Heresztyn, 1986a; Chatonnet et al., 1992; Cavin et al., 1993; Degrassi et al., 1995; Edlin et al., 1995; Cavin et al., 1997; Edlin et al., 1998; Shinohara et al., 2000; Van Beek \& Priest, 2000; Barata et al., 2006; Couto et al., 2006). The reduction step and ethylphenol formation occurs less frequently in microorganisms (Chatonnet et al., 1995; Barthelmebs et al., 2001), but is particularly effective in wine by the species D. bruxellensis and D. anomala (Edlin et al., 1995; Chatonnet et al., 1997; Dias et al., 2003a). Furthermore, S. cerevisiae are not able to produce ethylphenols (Chatonnet et al., 1993), and LAB, predominantly Lactobacillus spp., are only capable of producing low amounts under oenological conditions (Chatonnet et al., 1995; Couto et al., 2006). Recently, strains of Pichia guilliermondii have also been reported as producing considerable quantities of ethylphenols in grape must, to an extent similar to D. bruxellensis strains (Dias et al., 2003a). As P. guilliermondii have been recovered from grapes, grape juice and grape juice-related environments such as winery equipment, they have great significance for wine spoilage through the production of volatile phenols. However, these species are not capable of producing high levels of 4-ethylphenol in wine (Barata et al., 2006).

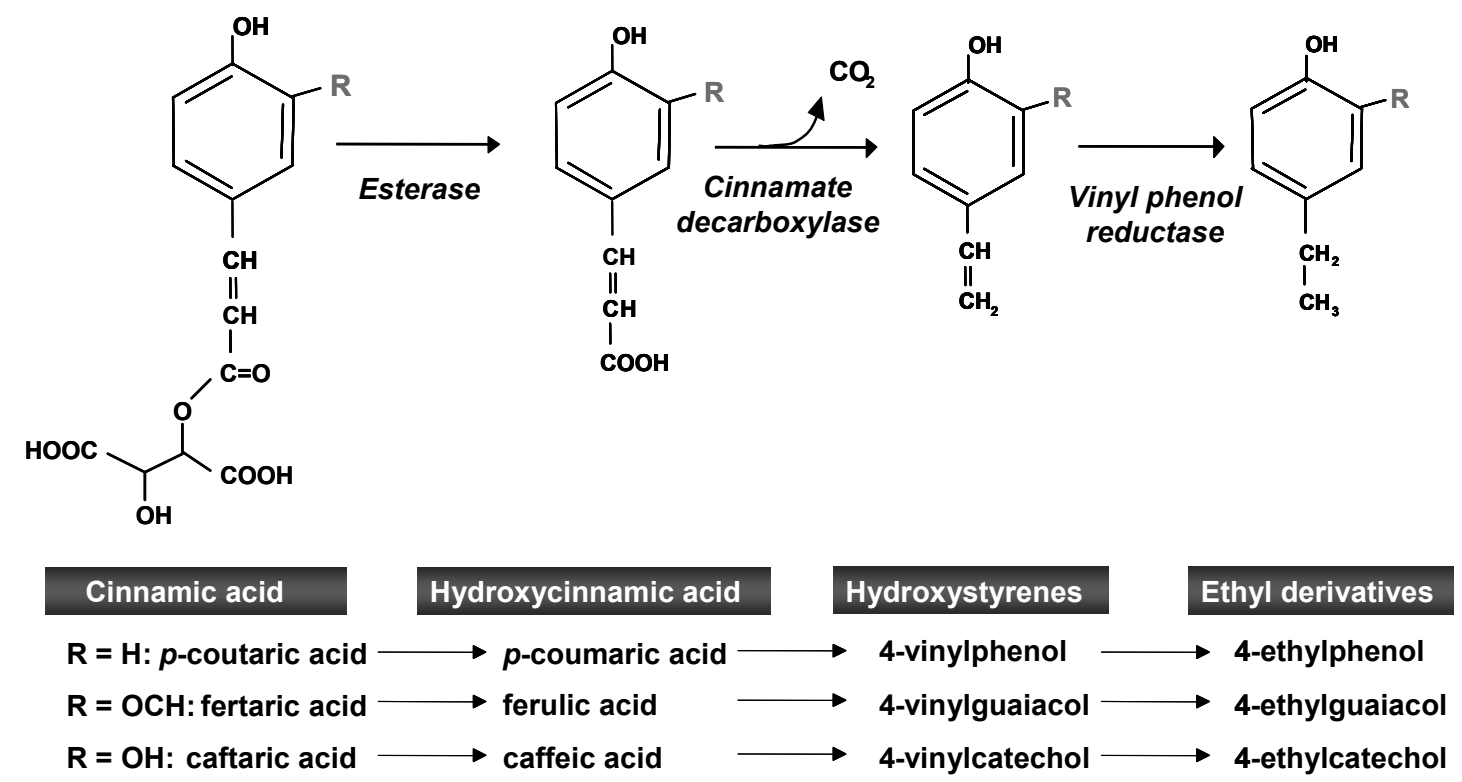

FIGURE 1

Formation of volatile phenols via the decarboxylation of hydroxycinnamic acids. 
TABLE 1

Aroma threshold values of volatile phenols in wine (Curtin et al., 2005).

\begin{tabular}{|c|c|c|c|}
\hline Compound & $\begin{array}{c}\text { Concentration } \\
\text { in red wine }(\mu \mathrm{g} / \mathrm{L})\end{array}$ & $\begin{array}{l}\text { Aroma threshold } \\
\qquad(\mu \mathrm{g} / \mathrm{L})\end{array}$ & Aroma descriptor \\
\hline 4-Vinylphenol & $8.8-4.3$ & $440 * / 600 * *$ & Phenol Medicinal \\
\hline 4-Vinylguaiacol & $0.2-15$ & $33 * / 110 * *$ & Clove-like \\
\hline 4-Ethylphenol & $118-3696$ & $30-60 * *$ & Horsy \\
\hline 4-Ethylguaiacol & $1-432$ & $20 * * *$ & Spicy, clove \\
\hline 4-Ethylcatechol & $27-427$ & $10 *$ & Phenol Band-Aid® Medicinal Banyard \\
\hline
\end{tabular}

*model wine, **red wine, ***water

Numerous studies have been performed to elucidate the role of volatile phenolic compounds and the formation of 'Brettanomyces character' in wine (Heresztyn, 1986a Chatonnet et al., 1992; 1995; 1997; Edlin et al., 1995; Licker et al., 1998; Dias et al., 2003b; Coulter et al., 2004; Hesford \& Schneider, 2004; Francis \& Newton, 2005). It has been found that the threshold concentrations of these compounds (Table 1), especially the ethyl derivatives, vary substantially and the perception of the individual aromas is greatly influenced by the wine style, cultivar and the consumer's perceptive abilities.

For more detailed overviews of wine spoilage by volatile phenols and the relevance of Brettanomyces/Dekkera yeasts also refer to Loureiro and Malfeito-Ferreira (2006) and Suárez et al. (2007).

\section{Other spoilage faults}

Brettanomyces/Dekkera yeasts have also been responsible for turbidity or haziness in wine (Van der Walt \& Van Kerken, 1958; Van Zyl, 1962) along with the production of several other metabolites that can contribute to wine spoilage. However, the conditions under which some of these are produced in wine and the exact mechanisms involved are not fully understood.

\section{Volatile acidity (VA) and other volatile fatty acids}

Brettanomyces/Dekkera spp. have long been known for their ability to affect wine quality negatively through the formation of acetic acid, which constitutes more than $90 \%$ of wine's volatile acidity (VA) (Van der Walt \& Van Kerken, 1958). Elevated levels of acetic acid can be detrimental to wine quality as it imparts a vinegary/ acetone-like aroma (Eglinton \& Henschke, 1999) and has also been associated with sluggish/stuck fermentations (Bisson, 1999). Brettanomyces/Dekkera yeasts have a particular metabolism that enables them to produce acetic acid (Licker et al. 1998; Loureiro \& Malfeito-Ferreira, 2006). M.T.J. Custers was the first to describe that the presence of oxygen stimulated glucose fermentation and that this led to the introduction of a biochemical characteristic known as the "negative Pasteur effect" (or 'Custers' effect') (Scheffers \& Wiken, 1969; Wijsman et al., 1984; Licker et al., 1998). Custers also determined that several strains of Brettanomyces were capable of producing considerable quantities of acetic acid under conditions of aerobiosis and found that anaerobic conditions inhibited glucose fermentation (Licker et al. 1998).

Recently, studies have shown that the availability of oxygen presents a favourable scenario for the development of Brettanomyces/Dekkera yeasts during winemaking as it supports their growth and survival and also acetic acid production (Ciani et al., 1997; Freer et al., 2003; Aguilar-Uscanga et al., 2003). In contrast, anaerobosis during alcoholic fermentation may well impede Brettanomyces/Dekkera growth, but would not necessarily prevent their development (Ciani et al., 1997). Therefore, the risk involved with VA formation by Brettanomyces/Dekkera spp. can be reduced by minimising the wine's exposure to oxygen (during racking and transfers) in combination with effective $\mathrm{SO}_{2}$ usage (Du Toit et al. 2005).

Other important volatile fatty acids produced by these yeasts that can have an impact on wine quality include: isovaleric acid (3-methylbutanoic acid), 2-methylbutyric and isobutyric acid (Olsen, 1994; Fugelsang, 1997; Licker et al., 1998). However, the focus of this review will fall on isovaleric acid as it can have a major sensory impact on wine aroma. Isovaleric acid has previously been found to be the dominant odorant in wines that were classified as containing a high degree of 'Brettanomyces character' (Licker et al., 1998). The aroma character of isovaleric acid has been described as 'rancid' following Gas Chromatography-Olfactometry (GC-O) analysis, although sensory panels often refer to 'sweaty' and 'cheesy' aromas when describing this compound (Coulter et al., 2004). Furthermore, although high concentrations of iso-valeric acid do not correlate with high levels of ethylphenols, it is believed that its presence may enhance the overall perception or intensity of other Brettanomyces-derived characters (Coulter et al., 2004). The exact cause and the conditions under which isovaleric acid is produced in wine are yet to be determined, but it is known that the amino acid degradation of L-leucine, L-isoleucine and L-valine are involved in the formation of isovaleric acid, 2-methylbutyric and isobutyric acid, respectively. The metabolic pathway of each of these volatile fatty acids can be seen in Figure 2 .

\section{Mousiness}

Another microbiologically produced off-flavour that can render the aroma and taste of wines unacceptable is 'mousiness'. Mousy off-flavour in wine was first reported by Heresztyn (1986b) who isolated and characterised the compounds responsible for this unpleasant aroma from wines contaminated with species of Lactobacillus and Brettanomyces. In light of the recent in-depth review on mousy off-flavour by Snowdon (2006) only the main aspects entailing Brettanomyces/Dekkera spp. will be mentioned.

Three chemical compounds have been identified as being responsible for mousy off-flavour in wine: 2-acetyltetrahydro- 


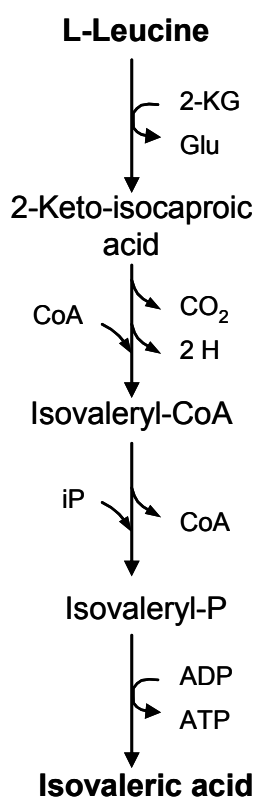

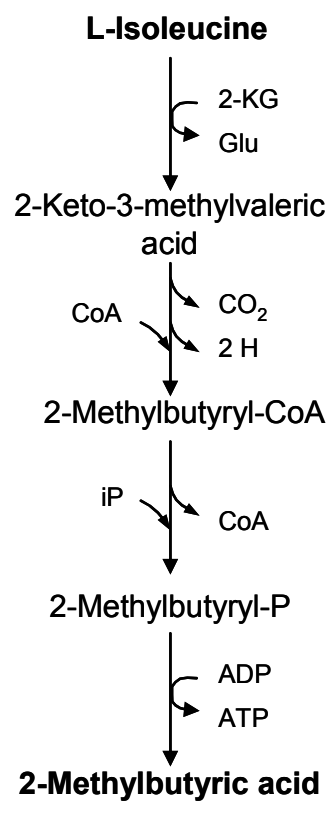

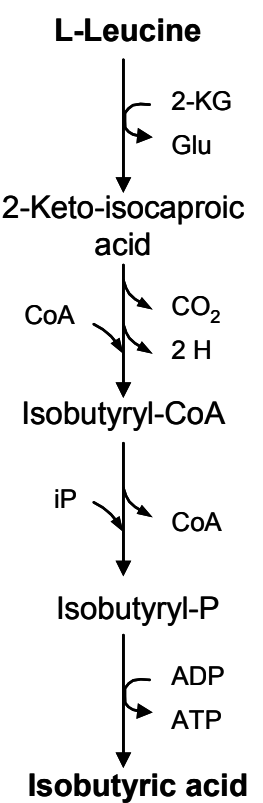

FIGURE 2

Formation of isovaleric acid (3-methylbutanoic), 2-methylbutyric and isobutyric acid (Harwood \& Canale-Parola, 1981).

A - ETHP

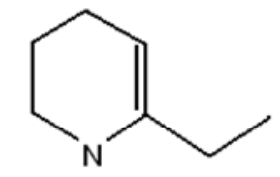

2-ethyltetrahydropyridine
B - ATHP

Imino form<smiles>CC(=O)C1=CCCCN1</smiles>

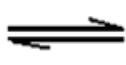

Amino form<smiles>CC(=O)C1=CCCCN1</smiles>

2-acetyl-3,4,5,6-tetrahydropyridine

2-acetyl-1,4,5,6-tetrahydropyridine

FIGURE 3

Chemical compounds produced by Brettanomyces/Dekkera yeasts responsible for mousy off-flavour (Snowdon et al., 2006).

pyridine (ATHP), 2-ethyltetrahydropyridine (ETHP) and 2-acetylpyrroline (APY) (Heresztyn, 1986b; Grbin et al., 1995). Of these, Brettanomyces/Dekkera yeasts are capable of producing only the first two (Fig. 3). ATHP appears to be the more prevalent in wine because this compound is normally detected in concentrations $(4.8-106 \mu \mathrm{g} / \mathrm{L})$ (Grbin et al., 1995) above its threshold value (1.6 $\mu \mathrm{g} / \mathrm{L})$ (Teranashi et al., 1975). ETHP has a much higher threshold value $(150 \mu \mathrm{g} / \mathrm{L})$ (Craig \& Heresztyn, 1984) but has only recently been detected in wines in much lower concentrations (Grbin et al., 1995).

The amino acid L-Lysine is essential in the formation of these two chemical compounds (Heresztyn, 1986b; Grbin et al., 1995; Grbin \& Henschke, 2000) and ethanol is a necessary precursor for the flavour to occur in wine (Snowdon et al., 2006). Additionally, oxygen has been indicated to have a stimulatory effect on the production of ATHP and ETHP (Grbin, 1998), but this is probably due to higher biomass formation of Brettanomyces/Dekkera strains under aerobic conditions. The aroma characters associated with ATHP are reminiscent of 'cracker biscuit' or 'popcorn', however due to the $\mathrm{pH}$ of wine, it is more apparent as a bitter, metallic palatable aftertaste. Mousy off-flavours occur infrequently in wine for reasons not fully understood. Chatonnet said: "These compounds are not of major significance when performing sensory screenings of 'Brettanomyces character' in wine'.

\section{Loss of colour}

Wines contaminated with Brettanomyces/Dekkera strains generally have an undesirable colour. A few reports are available that show glycosidic activity (b-glucosidase) amongst Brettanomyces/ Dekkera strains (Fugelsang et al., 1993; McMahon et al., 1999; Mansfield et al., 2002; Potgieter, 2004; Fia et al., 2005). In these cases, these yeasts may produce wines with enhanced aroma and complexity. On the other hand, a large part of the total glycoside concentration of grapes comprises mono-glucosylated anthocyanins, which are considered as the primary red pigments in Vitis vinifera (Somers et al., 1988). The hydrolysis of glucose usually results in the formation of a corresponding anthocyanin that can be converted to a colourless pseudobase, consequently affecting the 


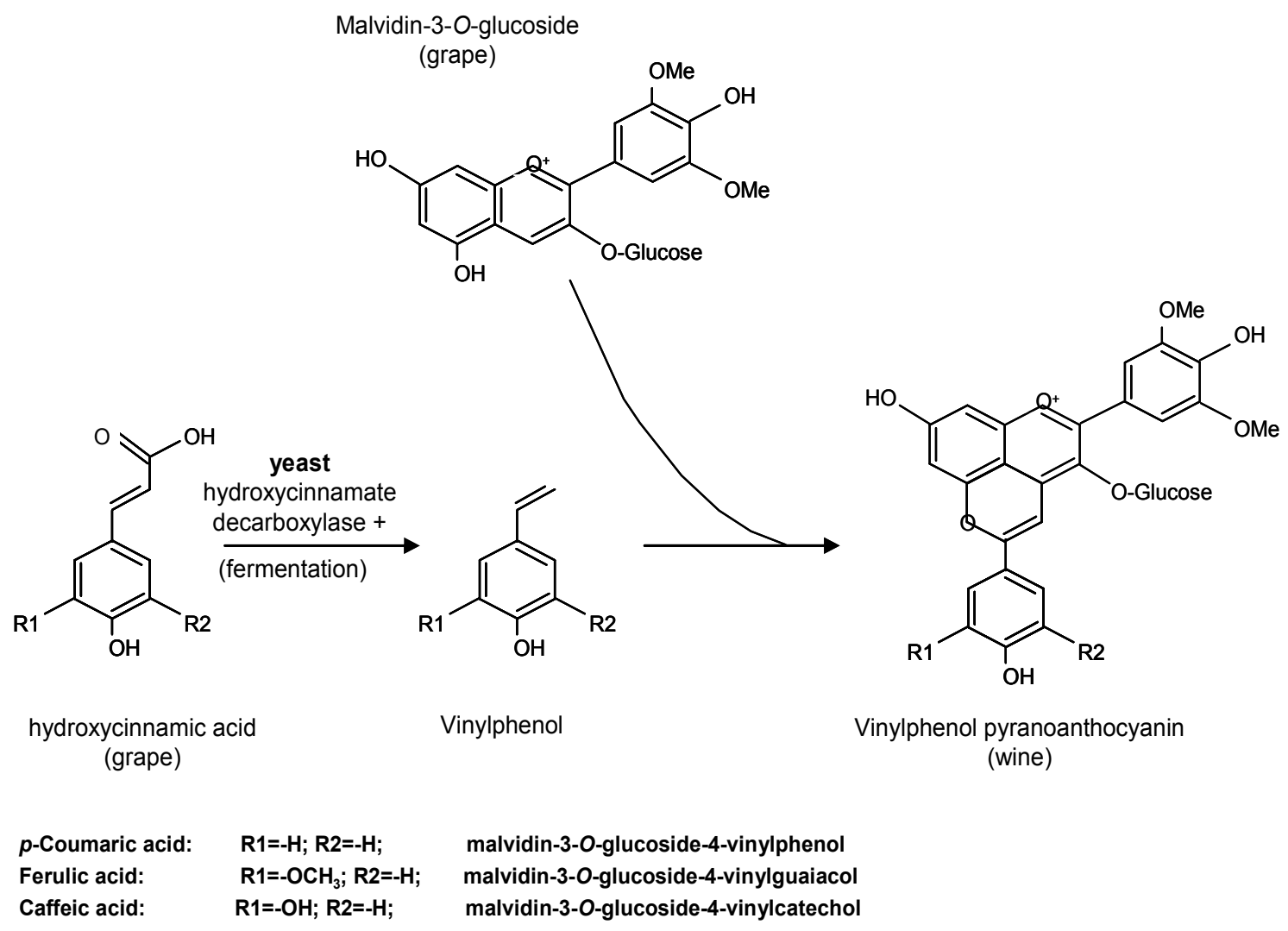

FIGURE 4

Formation of vinylphenolic pyranoanthocyanins during fermentation with yeasts showing hydroxycinnamate decarboxylase activity (Morata et al., 2007).

colour negatively (Mansfield et al., 2002). This may be a reason why some wines contaminated with Brettanomyces/Dekkera spp. have an undesirable colour (Suárez et al., 2007).

Another possible theory for loss of colour caused by Brettanomyces/Dekkera spp. is presented here. Wine colour is largely determined by various grape-derived anthocyanin pigments. Three types of pyranoanthocyanin pigments, namely vitisins, pyrano-anthocyanin-flavanols and vinylphenolic adducts, have recently been described to increase and stabilise the colour of the wine, particularly during ageing (Morata et al., 2007). The vinylphenolic pyranoanthocyanins result from the condensation of vinylphenols with grape anthocyanins, mainly malvidin-3-Oglucoside. Among the group of vinylderivatives, vinylcatechol, 4-vinylguaiacol and vinylphenol have been associated with the formation of vinylphenol malvidin adducts (Fulcrand et al., 1996; Francia-Aricha et al., 1997; Schwarz et al., 2003). The role of yeasts was explained by Morata et al. (2007) in that the fermentation by $S$. cerevisiae strains containing hydroxycinnamate decarboxylase activity is favourable for the formation of vinylphenolic adducts. In Figure 4, it can be seen how vinylphenols, formed from the decarboxylation of hydroxycinnamic acids, combine with grape anthocyanins (malvidin-3-O-glucoside) to generate vinylphenolic pyranoanthocyanins.

Along with the wine yeast $S$. cerevisiae and numerous other wine microorganisms, Brettanomyces/Dekkera yeasts also contain hydroxycinnamate decarboxylase activity (Heresztyn, 1986a; Chatonnet et al., 1992; Edlin et al., 1995) and are capable of producing vinylphenols (Clausen et al., 1994; Chatonnet et al., 1997; Couto et al., 2006). However, Brettanomyces/Dekkera yeasts are more likely to reduce the available vinylphenols to ethyl derivatives, consequently influencing the formation of vinylphenolic pyranoanthocyanins. Although this is highly speculative at this stage, it might explain the loss of colour as seen in severe cases of Brettanomyces/Dekkera contamination.

\section{Biogenic amines}

The metabolic activities of microorganisms may also give rise to the formation of biogenic amines (BA). These amines are produced via the decarboxylation of amino acids; e.g. histidine leads to the formation of histamine (Caruso et al., 2002). Most BA research has been undertaken into lactic acid bacteria, especially in fermented foods (Stratton et al. 1991; Simon-Sarkadi \& Holzapfel, 1994) but also in wine (Lonvaud-Funel, 2001). However, very few studies report on BA production by yeasts during winemaking. Caruso et al. (2002) evaluated the production of BA by various wine-related yeasts, including $B$. bruxellensis. They found that $B$. bruxellensis produced the highest concentration of total BA (average of $15 \mathrm{mg} / \mathrm{L}$ ) in comparison with other yeasts, despite exhibiting the weakest fermentative ability. The biogenic amines that were produced included: ethanolamine, methylamine, tryptamine, putrescine, cadaverine, histamine, agmatine and 2-phenylethylamine. Except for the last two amines, the majority of these were barely detectable. Also, considerable strain variability was seen with agmatine produced by $B$. bruxellensis (Caruso et al., 2002). In another study the formation of 2-phenylethylamine 
accounted for approximately $50 \%$ of the total BA produced by $B$. bruxellensis in a grape must fermentation (Granchi et al., 2005). Similar to the findings of Caruso et al. (2002), B. bruxellensis was the yeast species that produced the highest concentration of BA with an average value of $20 \mathrm{mg} / \mathrm{L}$.

The interest in BA in wine has been triggered as these compounds have been linked with unwanted physiological effects in people who show 'amine intolerance' (Gafner, 2003). The resulting symptoms include: headaches, nausea, diarrhoea and red skin colouration, to name a few. The ability of the human body to degrade BA is drastically affected by alcohol consumption as ethanol inhibits the enzyme diamine oxidase activity (DAO) responsible for converting BA to harmless products (Gafner, 2003). The toxicological importance of BA in wine still needs to be established along with the individual toxic thresholds. Nevertheless, the ability of Brettanomyces/Dekkera spp. to produce biogenic amines contributes to their general aptitude for spoiling wine.

\section{INVESTIGATIONS ON BRETTANOMYCES MANAGEMENT}

Due to the importance of Brettanomyces/Dekkera yeasts and their association with wine spoilage, it became evident that strategies for control, monitoring and risk management were needed. The incidences of Brettanomyces/Dekkera spoilage in wine have become more prominent during the past decade. Yap et al. (2007) attributed this largely to:

(i) recent trends in some winemaking styles - such as wines with higher $\mathrm{pH}$ values and residual sugar;

(ii) trends in winemaking practices - decreased use of filtration and $\mathrm{SO} 2$;

(iii) general poor cellar hygiene along with improper cleaning and sanitisation of barrels - a critical source of Brettanomyces/ Dekkera contamination of wine;

(iv) the spread of Brettanomyces/Dekkera between wineries and regions due to the use of contaminated barrels which are traded in the second hand barrel market; and

(v) importation of Brettanomyces/Dekkera-contaminated wine from other affected wineries.

The past decade has yielded reports that present valuable recommendations and strategies to the wine industry regarding the control and monitoring of Brettanomyces/Dekkera spp. This section will focus on and summarise the specific research investigations cited in peer-reviewed journals that focused on these aspects as well as highlighting other more general considerations.

\section{PREVENTATIVE MEASURES TO CONSIDER}

As Brettanomyces/Dekkera yeasts form a natural part of the winemaking process, they cannot entirely be eliminated. The spoilage caused by this species is inevitable in conditions favouring their proliferation. However, there are a few preventative measures that can be considered, although the issues relating to the complexity of microbiological spoilage in wine are not simply resolved with individual factors, but rather require a holistic approach.

Although there are still conflicts in literature about the origin of Brettanomyces/Dekkera spp., the vineyard can definitely play a role and grapes of sound quality can decrease some of the risks leading to the production of phenolic off-flavours (Loureiro \& Malfeito-
Ferreira, 2006; Taillandier, 2007). In addition, the concentrations of the hydroxycinnamic acid precursors directly responsible for Brettanomyces/Dekkera phenolic off-flavours can depend on grape variety, quality (Phister \& Mills, 2003) and maceration practices. Gerbaux et al. (2002) studied the effect of maceration temperature (heating) and intensity on the release of hydroxycinnamic acids from grape skins as factors influencing the formation of volatile phenols by Brettanomyces/Dekkera spp. These factors, along with enzymes used for colour extraction and clarification, such as pectolytic and other enzymes containing cinnamoyl esterase activity, can lead to increased levels of volatile phenol production by Brettanomyces/ Dekkera spp. (Dugelay et al., 1993; Gerbaux et al., 2002).

Yeast selection can also play a crucial role. There are several criteria to consider when it comes to selection of commercial $S$. cerevisiae starter cultures (Degré, 1993). These are especially important for the prevention of stuck or sluggish fermentations (Malherbe et al., 2007), which create an environment for any form of microbial spoilage to occur. The specific aspect of wine yeasts relating to Brettanomyces/Dekkera produced off-flavours revolves around their ability to produce vinylphenols via the decarboxylation of cinnamates (Clausen et al., 1994). S. cerevisiae strains differ in their ability to produce vinylphenols (Van Wyk \& Rogers, 2000; Nelson, 2008) and higher levels of vinyl derivatives can consequently lead to objectionable concentrations of ethylphenols by D. bruxellensis. Conversely, vinylphenols are involved in the formation of pyranoanthocyanins and at higher levels these can also be beneficial to the stability and intensity of colour in wine (Morata et al., 2007). It remains to be ascertained which aspect of hydroxycinnamic acid decarboxylation by wine yeast is more important.

\section{FACTORS FOR CONTROLLING BRETTANOMYCES/ DEKKERA}

\section{Sulfur dioxide $\left(\mathrm{SO}_{2}\right)$}

The antimicrobial potential of $\mathrm{SO}_{2}$ makes it ideal for wine preservation, in particular for reducing microbiological instabilities (Romano \& Suzzi, 1993). Regarding, $\mathrm{SO}_{2}$ and its effect on the yeast $D$. bruxellensis, studies have yielded incoherent results as this species is regarded as either sensitive or resistant (Loureiro $\&$ Malfeito-Ferreira, 2006). Some authors found this yeast to be sensitive to free $\mathrm{SO}_{2}$ concentrations exceeding $30 \mathrm{mg} / \mathrm{L}$ (Chatonnet et al., 1992; Gerbaux et al., 2002), explaining why it is frequently isolated from wines with low $\mathrm{SO}_{2}$ protection (Heresztyn, 1986a). Others observed yeast growth with concentrations of free $\mathrm{SO}_{2}$ of above $30 \mathrm{mg} / \mathrm{L}$, reflecting the resistance of certain $D$. bruxellensis strains (Van der Walt \& Van Kerken, 1961; Froudière \& Larue, 1988). This controversy, however, does not lie in the free form of $\mathrm{SO}_{2}$, but rather in the actual effectiveness of its molecular form (Boulton et al., 1996; Margalit, 1997; Ribéreau-Gayon, 2000), which is dependent on many variations in wine composition $(\mathrm{pH}$, ethanol, temperature, anthocyanin levels and nutrient content) (Smith, 1996 in Licker et al. 1998). For example, the concentration of molecular $\mathrm{SO}_{2}$ is $\mathrm{pH}$-dependent and $30 \mathrm{mg} / \mathrm{L}$ of free $\mathrm{SO}_{2}$ can release $0.4 \mathrm{mg} / \mathrm{L}$ of molecular $\mathrm{SO}_{2}$ at $\mathrm{pH} 3.7$, and $0.8 \mathrm{mg} / \mathrm{L}$ at $\mathrm{pH}$ 3.4 (Margalit, 1997). The use of 0.5 to $0.8 \mathrm{mg} / \mathrm{L}$ molecular $\mathrm{SO}_{2}$ has been recommended to control Brettanomyces/Dekkera spp. (Henick-Kling et al., 2000). The effectiveness of molecular $\mathrm{SO}_{2}$ on a strain of $B$. bruxellensis has also been linked with oxygen availability (Du Toit et al., 2005). The authors reported that 0.25 
$\mathrm{mg} / \mathrm{L}$ of molecular $\mathrm{SO}_{2}$ drastically affected the cultureability of the strain, however, the strain remained viable and increased in numbers after exposure to oxygen. This is especially of importance during racking and transfers throughout barrel ageing. Barrels can also reduce $\mathrm{SO}_{2}$ levels over a period of four to six months of ageing (Chatonnet et al., 1993) and therefore $\mathrm{SO}_{2}$ management is crucial during this time. This agrees with anecdotal evidence that new barrels can absorb up to $15 \mathrm{mg} / \mathrm{L}$ of free $\mathrm{SO}_{2}$ over the same time period (Coulter et al., 2004).

A survey done by the Australian Wine Research Institute (AWRI) revealed a tendency among Australian winemakers to use many smaller $\mathrm{SO}_{2}$ additions, as opposed to larger, less frequent additions during winemaking. This is not advised as it can lead to the unintentional selection or build-up of more resistant yeast species, including Brettanomyces/Dekkera spp. (Coulter et al., 2004).

\section{Other additives}

In addition to $\mathrm{SO}_{2}$ usage, alternative additives have also been investigated as growth inhibitors for Brettanomyces/Dekkera yeasts (Loureiro \& Malfeito-Ferreira, 2006; Suárez et al., 2007). Dimethyl dicarbonate (DMDC), also commercially known as Velcorin ${ }^{\circledR}$, has been evaluated for Brettanomyces/Dekkera yeast inhibition. It was found that DMDC could not completely inhibit the growth of $B$. anomalus with a dosage of $400 \mathrm{mg} / \mathrm{L}$, but 250 $\mathrm{mg} / \mathrm{L}$ inhibited the fermentation of $B$. bruxellensis (Delfini et al., 2002). A very recent study described the effectiveness of DMDC for the prevention of $B$. bruxellensis in wine and evaluated its use during different winemaking stages (Renouf et al., 2007). The authors obtained variable results with strains of $B$. bruxellensis showing moderate resistance with $150 \mathrm{mg} / \mathrm{L} \mathrm{DMDC}$ in grape must and $250 \mathrm{mg} / \mathrm{L}$ causing only a transitory inhibition during MLF. The effectiveness of DMDC was, however, dependent on ethanol content (Malfeito-Ferreira et al., 2004). It was also found that DMDC did not completely eliminate $B$. bruxellensis populations in the presence of lees at $200 \mathrm{mg} / \mathrm{L}$ (Renouf et al., 2007). On the other hand, in finished wines the B. bruxellensis population declined to less than $100 \mathrm{cfu} / \mathrm{mL}$. Renouf et al. (2007) advised against the use of DMDC before the end of MLF as it can act on fermenting species such as $S$. cerevisiae and Oenococcus oeni and instead recommended the use of DMDC prior to bottling. Regular additions up to $200 \mathrm{mg} / \mathrm{L}$ (maximum permitted level in wine) can help to control Brettanomyces growth during barrel maturation (Loureiro \& Malfeito-Ferreira, 2006) in countries where its use is allowed.

The effect of DMDC is not directly $\mathrm{pH}$ dependent (Threlfall \& Morris, 2002) and it yields no residual odours or flavours (Ough, 1983). The use of DMDC requires an approved dosing machine and must be carefully handled.

Weak acids, such as sorbic, benzoic and fumaric acids have also been investigated for use against Brettanomyces/Dekkera spp. as they contain antifungal activity. D. bruxellensis are regarded as one of the most tolerant species to sorbic acid and dissolved carbon dioxide (Ison \& Gutteridge, 1987; Loureiro, 1997). Although these weak acids are included in selective media (Chatonnet et al., 1992, Rodriquez et al., 2001), they are not favourable during winemaking and face consumer resistance (Pretorius, 2000; Suárez et al., 2007). Weak-acid preservatives have been shown to be more effective at low $\mathrm{pH}$ values, and that inhibition depended on the actual intracellular concentration of the individual preservatives (Quintas et al., 2005). An indirect measure to prevent ethylphenol formation during ageing involves the use of antioxidants such as, ascorbic and erythorbic acids (Suárez et al., 2007). Antioxidants can be used to reduce the presence of oxygen, thereby being indirectly detrimental to the proliferation of Brettanomyces/Dekkera yeasts.

\section{Haziness/Fining agents}

Protein or microbial instabilities are well known for causing turbidity or haziness in wines. This has also been addressed as an issue relating to wine spoilage by Brettanomyces/Dekkera after wineries, which apparently practiced effective $\mathrm{SO}_{2}$ and $\mathrm{pH}$ management, barely showed a reduction of 4-ethylphenol concentrations (Coulter et al., 2004). In such instances, the effectiveness of $\mathrm{SO}_{2}$ was compromised as it is rapidly bound. Suárez et al. (2007) summarised numerous investigations of fining agents and their impact on Brettanomyces/Dekkera yeasts during winemaking. Brettanomyces populations can be reduced by 40 to 2000 -fold by treatments with fining proteins (Murat \& Dumeau, 2003). Brettanomyces/Dekkera yeasts in a red wine have also been decreased from an initial population of $10^{4} \mathrm{cfu} / \mathrm{mL}$ to $170 \mathrm{cfu} / \mathrm{mL}$ after fining with liquid gelatine at a dosage of $0.6 \mathrm{ml} / \mathrm{L}$ (Suárez et al., 2007).

\section{Filtration}

Studies that pertain to wine filtration for the removal of Brettanomyces/Dekkera cells have also been performed (Calderón et al., 2004). The authors reported effective removal of Brettanomyces cells using membranes with a pore size smaller than $0.45 \mu \mathrm{m}$. Millet and Lonvaud-Funel (2000) studied the VBNC state of wine microorganisms during storage. It was found that non-culturable cells could pass through the $0.45 \mu \mathrm{m}$ filtration and it is believed that Brettanomyces cells can possibly reduce their cellular size when entering the VBNC state. This is a very interesting phenomenon considering that the average size of Brettanomyces spp. is (5-8) x (3-4) $\mu \mathrm{m}$ (Millet \& LonvaudFunel (2000). This might explain why some wines are still subjected to Brettanomyces/Dekkera spoilage after they have been declared sterile by agar plate enumerations. The VBNC state of microorganisms, particularly of Brettanomyces/Dekkera spp., is an area that needs to be further explored. Moreover, the importance of molecular DNA-based identification techniques is amplified by the shortcomings of microbiological plating techniques. The use of smaller pore sizes during filtration (e.g. cross-flow with 0.22 $\mu \mathrm{m}$ ) is recommended for wines destined to be used for toppingup barrels during ageing (Oelofse \& Du Toit, 2006). However, filtration poses similar problems to fining as it can be detrimental to the colloidal structure of wine and can lead to a loss of colour (Suárez et al., 2007). It should therefore be carefully considered.

\section{Alternative methods}

The use of a polysaccharide derived from chitin, called chitosan, has been reported to exert a selective pressure on the growth of B. bruxellensis in a mixed bioethanol fermentation with $S$. cerevisiae (Gómez-Rivas et al., 2004). The presence of 3-6 g/L of chitosan drastically decreased the growth of $B$. bruxellensis and $B$. intermedius in this study.

The application of high pressure on wine has also been investigated. Total microbial populations comprising AAB, LAB and yeasts (including Brettanomyces spp.) could be reduced by $99 \%$ by pressures of 400 or $500 \mathrm{MPa}$ for 5 or $15 \mathrm{~min}$ at 4 or $20^{\circ} \mathrm{C}$, respectively (Puig et al., 2003). Wine pasteurisation using 
high hydrostatic pressures have been shown not to cause major modifications to the physiochemical and sensorial properties of wine (Mok et al., 2006). However, the application of this treatment in oenology still requires a lot of study for the development of appropriate equipment.

The use of temperature for the inactivation of Brettanomyces/ Dekkera yeasts in wine has also been investigated. Couto et al. (2005b) found that a population of $10^{6} \mathrm{cfu} / \mathrm{mL}$ could be thermally inactivated with a $37.5^{\circ} \mathrm{C}$ for $6 \mathrm{~min}$ and $41^{\circ} \mathrm{C}$ for $0.6 \mathrm{~min}$ treatment. The concern about this approach is its impact on the aroma and flavour characteristics of wine, if the treatment is not carefully controlled.

An alternative strategy to chemical preservation involves the use of antimicrobial agents as part of biopreservation (Pretorius, 2000). Biological control with various antimicrobial agents, such as zymocins is currently being considered, but their efficiency in wine is yet to be determined (Du Toit \& Pretorius, 2000). Recently, a potential application of antimicrobial agents active on Brettanomyces/Dekkera yeasts during wine ageing and storage has also been hypothesised. Comitini et al. (2004) described the use of two killer toxins produced by Pichia anomala (DBVPG 3003) and Kluyveromyces wickerhamii (DBVPG 6077) that have fungicidal activity against $D$. bruxellensis. The two toxins named Pikt and Kwkt are stable in wine for at least 10 days and show potential use for the future. However, the purification and use of antimicrobial agents might be expensive.

\section{CURATIVE MEASURES FOR VOLATILE PHENOLS}

In addition to the methodologies that have been investigated for controlling the microbiological aspects of Brettanomyces/Dekkera spp. contamination, there are also some control strategies pertaining to the specific chemical aromas or phenolic off-flavours produced. The volatile phenols, specifically the ethylphenols, which result from a Brettanomyces/Dekkera contamination, can also be reduced.

Ugarte et al. (2005) obtained a 77\% reduction in the total ethylphenols (4-EG and 4-EP) by using reverse osmosis and adsorption. The three hour process comprised a hydrophobic absorbent resin and a membrane with tangential-flow filtration. However, a reduction in some aromatic compounds, namely ethyland methyl vanillate and other esters, was also obtained.

Other absorbents commonly used during winemaking have also been reported to reduce off-flavours and odours. Polyvinylpolypyrrolidone (PVPP) and charcoal are used by some winemakers to lower ethylphenol levels (Suárez et al., 2007). The prescribed amounts vary and range from $60-480 \mathrm{mg} / \mathrm{L}$ for PVPP and $15-240 \mathrm{mg} / \mathrm{L}$ for charcoal, depending on the intensity of the off-flavours. Fining agents such as casein and potassium caseinate also present an absorptive function and have been used to reduce low levels of ethylphenols (Ruiz-Hernández, 2003). The adsorption of volatile phenols by using active dried wine yeast and yeast lees as a biosorbent was also investigated (Chassagne et al., 2005). This came after decreases in the contents of 4-EP and 4-EG were found in red wine containing yeast lees compared to the same wine aged without lees (Guilloux-Benatier et al., 2001). The authors found that active dried yeast of $S$. cerevisiae removed $33 \%$ and $26 \%$ of the 4-EP and 4-EG concentrations, respectively, in a model wine solution (Chassagne et al., 2005). It was speculated that the rapid adsorption process occurs predominantly by yeast surface binding. The affinity of yeast lees for volatile phenol adsorption was sensitive to the level of yeast autolysis and physicochemical parameters, such as ethanol content, temperature and $\mathrm{pH}$.

\section{CONSEQUENCES OF OAK BARRELS AND CONTROL}

Another aspect of winemaking that is increasingly gaining substantial attention, involves the role of oak barrels and their effect on microbial wine spoilage. Wooden barrels are particularly known as an ecological niche where microbial spoilage can occur, especially by yeasts such as D. bruxellensis (Swaffield \& Scott, 1995; Laureano et al., 2005). Due to the difficulty of sanitising barrels several concerns have been raised regarding the control of Brettanomyces/Dekkera spp. during barrel ageing and storage of wine.

Brettanomyces/Dekkera yeasts are known to survive in barrels in areas where they are protected against treatments such as $\mathrm{SO}_{2}$. These include the yeast lees, around bung holes and in the oak structure (Laureano et al., 2005). The penetrative capacity of the wine serves as a vector for carrying these yeasts deep into the cracks and crevices of staves (up to $8 \mathrm{~mm}$ ) (Fugelsang, 1997; Laureano et al., 2005). Here, the cells have a large degree of protection against $\mathrm{SO}_{2}$ gas allowing them to establish themselves (Fugelsang, 1997; Swaffield et al., 1997). The survival of established microbial populations becomes a greater sanitary issue with used barrels (Chatonnet et al., 1999) as the pores become impregnated or blocked by microbial cells, colour pigments and other colloidal materials. This is further complicated by the presence of fungal growth and the formation of microbial biofilms (Yap et al., 2007). The influence of biofilms on wood structure and wine spoilage is not well characterised. However, biofilms are reportedly up to 1000 times more resistant to chemical cleaning agents and sanitisers (Kumar \& Anand, 1998; Lewis, 2001). In this regard, Joseph and Bisson (2004) found that $50 \%$ from a total of 35 Brettanomyces/Dekkera isolates could form biofilms, which adds another dimension to their control.

Barrel cleaning and sanitation is very difficult and there are many inconsistencies in literature as to which methodologies are most effective. Chatonnet et al. (1992) advised that the sanitation of barrel wood requires at least $7 \mathrm{~g}$ of $\mathrm{SO}_{2}$ gas per barrel. HenickKling et al. (2000) recommends that filled barrels should receive approximately 30-35 mg/L free $\mathrm{SO}_{2}$ during summer months. A recent study by Laureano et al. (2005) evaluated different treatments on used French barrels (third fill) that contained red wine with high ethylphenol levels and culturable D. bruxellensis cells. These included: (i) cold water rinse followed by three hot water rinses at $70^{\circ} \mathrm{C}$ and air-drying; (ii) same as above plus filling with an aqueous solution of $\mathrm{SO}_{2}(200 \mathrm{mg} / \mathrm{L}, \mathrm{pH} 3)$ and storing for one month; (iii) cold water rinse, followed by filling the barrel three-quarters full with hot water at $90^{\circ} \mathrm{C}$ for $10 \mathrm{~min}$; and (iv) cold water rinse, followed by a $70^{\circ} \mathrm{C}$ hot water rinse and steaming under low pressure $(0.5 \mathrm{~kg} / \mathrm{cm})$ for $10 \mathrm{~min}$. It was found that the treatment with steam was the most effective, although none of the approaches was able to significantly reduce the microbial populations as D. bruxellensis cells were still recovered from the external surfaces of grooves, side surfaces of staves $(2-4 \mathrm{~mm})$ and at the bunghole (4-6 mm).

Studies concerning the use of ozone have also been reported. Cantacuzene et al. (2003) evaluated the effect of aqueous ozone and ozone gas on B. bruxellensis contaminated oak cubes. The authors found a reduction of the Brettanomyces population with 
TABLE 2

Summary of investigations on Brettanomyces/Dekkera control.

Treatment
Protein clarification

Gelatine

Reference

Egg white

Murat \& Dumeau (2003)

Ruiz-Hernández (2003)

Potassium caseinate

Caseins

\section{Filtration}

Membranes $(0.45 \mu \mathrm{m})$

Ultrafiltration

\section{Physicochemical variables}

Low aging temperature

Low $\mathrm{pH}$

Reduction of oxygen content

Avoidance of micro-oxygenation

High alcohol levels

\section{Reduction of precursor concentration}

Low maceration temperature

Avoidance of pectolytic enzymes and enzymes with cinnamoyl esterase activity

\section{Additives \\ $\mathrm{SO}_{2}$ \\ DMDC \\ Chitosan \\ Sorbic acid \\ Benzoic acid \\ Fumaric acid \\ Ascorbic acid \\ Erythorbic acid}

\section{High pressure processing}

400-500 MPa

\section{Biological techniques}

Zymocins/killertoxins

Bacteriological enzymes

\section{Genetic egineering}

Transgenic yeasts

\section{Other alternatives}

Ozone

Reverse osmosis

Absorbents

PVPP

Charcoal

Ultrasonics
Millet \& Lonvaud-Funel (2000)

Calderón et al . (2004)

Gerbeaux et al . (2000)
Ison \& Gutteridge (1987)

Delfini et al . (2002)

Renouf et al . (2007)

Gómez-Rivas et al . (2004)
Puig et al . (2003)

Du Toit \& Pretorius (2000)

Comitini et al . (2004)

Du Toit \& Pretorius (2000)

Guilloux-Benatier (2001)

Coggan (2003)

Cantacuzene et al . (2003)

Chassagne et al . (2005)

Yap et al . (2007) the ozone gas and with a hot water treatment $\left(82^{\circ} \mathrm{C}\right.$ for $\left.20 \mathrm{~min}\right)$, but not with the aqueous ozone. In contrast, Brettanomyces populations were reduced by up to $99 \%$ with ozonated water in another investigation (Coggan, 2003). Despite many anecdotal reports, ozone sanitation has been used with good results and is strongly recommended for stainless steel tanks.

Barrel shaving and re-firing have also been investigated by Pollnitz et al. (2000) who found that the wine contained up to $85 \%$ less 4-EP and 4-EG after being stored in shaved and re-fired barrels in comparison to control barrels (untreated barrels). This was attributed to a reduced microbial population on the inner surface of barrels, which confirmed the prevalence of viable Brettanomyces/ Dekkera cells in the wood structure (Pollnitz et al., 2000).

One of the latest additions to barrel cleaning and disinfection techniques use high-power ultrasonics (Yap et al., 2007). Laboratory tests have proven that ultrasound or sonification 
could effectively kill viable cells of $D$. bruxellensis in synthetic media. More than $97 \%$ of the population of $4.4 \times 10^{6} \mathrm{cfu} / \mathrm{mL}$ were destroyed with ultrasound power at 50 watts for 90 to $120 \mathrm{~s}$. Further trials directly in wine are anticipated.

Regarding barrel cleaning, there currently appears to be no substantial scientific evidence on which approach will guarantee complete sterilisation. Barrels are often, if not in most cases, impossible to sterilise and the effectiveness of all the abovementioned procedures is highly doubted (Boulton et al., 1996; Pollnitz et al., 2000; Arvik \& Henick-Kling, 2002; MalfeitoFerreira et al., 2004). In addition to the uncertainties, there are currently no reliable techniques that allow for the direct detection for Brettanomyces/Dekkera spp. in wood. This should be considered for future investigations in order to reveal the true value of the various barrel sanitation techniques.

The possibility that new oak barrels can be beneficial for the growth and survival of the Brettanomyces/Dekkera population that is carried by the wine has also been hypothesised (LonvaudFunel \& Renouf, 2005). This speculation has value as new barrels provide greater sugar resources (higher cellubiose levels) and oxygen contributions than older barrels (Swaffield \& Scott, 1995; Boulton et al., 1996; Loureiro \& Malfeito-Ferreira, 2006; Yap et al., 2007). However, new oak is not a source of contamination, since wood is not the natural habitat for the yeast. Moreover, it is expected that the toasting process eliminates new barrels as a source of Brettanomyces/Dekkera contamination. Problems related to new barrels are most likely to be caused by poor barrel management at wineries, e.g. pre-rinsing with non-sterile water.

Several recommendations for the control, monitoring and curative procedures of Brettanomyces/Dekkera spoilage in wine have been formulated over the years (Godden et al., 2004). Combined results from scientific investigations and empirical findings currently indicate that the success relating to the control of Brettanomyces/Dekkera-associated spoilage in wine evolves around a holistic approach. More detailed recommendations for the control of Brettanomyces/Dekkera yeasts during winemaking can also be found in Coulter et al. (2004), Loureiro and MalfeitoFerreira (2006), Oelofse and Du Toit (2006) and Suárez et al. (2007). A summary of all the scientific investigations on the control of Brettanomyces/Dekkera yeasts discussed in this overview can be seen in Table 2 .

\section{CONCLUSIONS}

The microbiology of wine is very complex and this often makes it difficult to pinpoint the exact problem and its origin in a habitat such as wine when spoilage does occur. Nonetheless, large-scale investigations on controlling wine spoilage have been conducted for many years in an attempt to improve wine quality and great progress has been made in the past decade.

With regards to Brettanomyces/Dekkera yeasts, only small steps have been taken and there are still many factors to be researched. These yeast species are only a few of the many organisms that exist in the winemaking environment and, because they are living entities, there will be a lot of diversity among their species. Despite their economic importance and the increasing amount of interest by the wine industry, Brettanomyces/Dekkera spp. have been largely understudied at genetic level. It is for this reason that a genome sequence project on this wine spoilage yeast has recently been initiated (Woolfit et al., 2007). Preliminary results indicate that the proteome of $D$. bruxellensis is rich in transporters and genes involved in lipid and nitrogen metabolism. This may well elucidate their ability to survive in an environment with high ethanol and nutrient limitation. Future studies on the genetic characterisation of this species will resolve their true significance during winemaking.

\section{LITERATURE CITED}

Aguilar-Uscanga, M.G., Delia, M.L. \& Strehaiano, P., 2003. Brettanomyces bruxellensis: Effect of oxygen on growth and acetic acid production. Appl. Microbiol. Biotechnol. 61, 157-162.

Alguacil, M., Fidalgo, M., Jimenez, J., Lozano, J., Neva, M. \& Perdigones, F., 1998. Detecion de Dekkera/Brettanomyces en instalaciones de vendemia mediante PCR. Alimentos Equipos Technol. 10, 81-85.

Arvik, T.J., Conterno, L. \& Henick-Kling, T., 2002. Brettanomyces bruxellensis in New York State wines: a global issue. In: Henick-Klink, T. (ed). Proc. $31^{\text {st }}$ Annual New York Wine Industry Workshop, April 3-5, Cornell University, New York State, pp. 124-125.

Barata, A., Nobre, A., Correia, P., Malfeito-Ferreira, M. \& Loureiro, V., 2006. Growth and 4-ethylphenol production by the yeast Pichia guilliermondii in grape juices. Am. J. Enol. Vitic. 57, 133-138.

Barnett, J., Payne, R. \& Yarrow, D., 2000 ( ${ }^{\text {rd }}$ ed). Yeasts: Characteristics and identification. Cambridge, Cambridge University Press.

Barthelmebs, L., Diviès, C. \& Cavin, J.F., 2001. Molecular characterization of the phenolic acid metabolism in the lactic acid bacteria Lactobacillus plantarum. Lait 81, 161-171.

Bellon, J., Robinson, E., Cowey, G., Graves, P., Field, J., Godden, P. \& de Barros Lopes, M., 2003. The degree of genetic variation between strains of Dekkeral Brettanomyces yeast isolated from different Australian wineries and regions. In: Bell, S.M., de Garis K.A., Dundon C.G., Hamilton R.P., Partridge S.J. \& Wall G.S. (eds). Proc. Sem. Aus. Soc. Vitic. Oenol. - Grapegrowing at the edge, managing the wine business, impacts on wine flavour. Australian Society for Viticulture and Oenology, Adelaide, SA, pp. 51-55.

Bisson, L., 1999. Stuck and sluggish fermentations. Am. J. Enol. Vitic. 50, 107119.

Boekhout, T., Kurtzman, C., O’Donnell, K. \& Smith, M.T., 1994. Phylogeny of the yeast genera Hanseniaspora (anamorph Kloeckera), Dekkera (anamorph Brettanomyces), and Eeniella as inferred from partial 26S ribosomal DNA nucleotide sequences. Int. J. Syst. Bacteriol. 44, 781-786.

Boekhout, T., Robert, V., Smith, M., Stalpers, J., Yarrow, D., Boer., P., Gijswijt, G., Kurtzman, C., Fell, J., Guého, E., Guillot, J. \& Roberts, I., 2002. Yeasts of the World - Morphology, physiology, sequences and identification. CD-ROM from ETI information services, Ltd, Wokingham, UK.

Boulton, R.B., Singleton, V., Bisson, L.F. \& Kunkee, R., 1996. Principles and Practices of Winemaking. Chapman \& Hall Publishers New York, NY.

Calderón, F., Morata, A., Uthurry, C. \& Suárez, J.A., 2004. Aplicaciones de la ultrafiltración en la industria enológica. Ultimos avances tecnológicos. Tecnología del Vino 16, 49-54

Cantacuzene, N.O., Dormedy, E.S., Smilanick, J.L., Fugelsang, K.C., Wample, R.L., Bacon, D.J. \& Dormedy, D.F., 2003. Treating Brettanomyces in oak cubes with gaseous and aqueous ozone. In: ASEV 54th annual meeting, Reno, Nevada.

Caruso, M., Fiore, C., Contrusi, M., Salzano, G., Paparella, A. \& Romano, P., 2002. Formation of biogenic amines as criteria for the selection of wine yeasts. World J. Microbiol. Biotechnol. 18, 159-163.

Cavin, J.F., Andioc, V., Etiévant, P.X. \& Diviès, C., 1993. Ability of wine lactic acid bacteria to metabolize phenol carboxylic acids. Am. J. Enol. Vitic. 44, 76-80.

Cavin, J.F., Barthelmebs, L., Guzzo, J., Van Beeumen, J., Samyn, B., Travers, J.F. \& Diviès, C., 1997. Purification and characterization of an inducible $p$-coumaric acid decarboxylase from Lactobacillus plantarum. FEMS Microbiol. Lett. 147, 291-295.

Chassagne, D., Guilloux-Benatier, M., Alexandre, H. \& Voilley, A., 2005. Sorption of wine volatile phenols by yeast lees. Food Chem. 91, 39-44. 
Chatonnet, P., Boidron, J.N. \& Dubourdieu, D., 1993. Influence des conditions d'élevage et de sulfitage des vins rouges en barriques sur leur teneur en acide acétique et en ethyl-phenols. J. Int. Sci. Vigne Vin 27, 277-298.

Chatonnet, P., Dubourdieu, D. \& Boidron, J.N., 1995. The influence of Brettanomyces/Dekkera sp. yeasts and lactic acid bacteria on the ethylphenol content of red wines. Am. J. Enol. Vitic. 46, 463-468.

Chatonnet, P., Dubourdieu, D., Boidron, J. \& Pons, M., 1992. The origin of ethylphenols in wines. J. Sci. Food Agric. 60, 165-178.

Chatonnet, P., Masneuf, I., Gubbiotti, M.C. \& Dubourdieu, D., 1999. Prévention et détection des contaminations par Brettanomyces au cours de la vinification et de l'élevage des vins. Rev. Fr. Oenol. 179, 20-24.

Chatonnet, P., Viala, C. \& Dubourdieu, D., 1997. Influence of polyphenol components of red wines on the microbial synthesis of volatile phenols. Am. J. Enol. Vitic. 48, 443-447.

Ciani, M. \& Ferraro, L., 1997. Role of oxygen on acetic acid production by Brettanomyces/Dekkera in winemaking. J. Sci. Food Agric. 75, 489-495

Clausen, M., Lamb, C.J., Megnet, R. \& Doerer, P.W., 1994. PAD1 encodes phenylacrylic acid decarboxylase which confers resistance to cinnamic acid in Saccharomyces cerevisiae. Gene 142, 107-112.

Cocolin, L., Rantsiou, K., Iacumin, L., Zironi, R. \& Comi, G., 2004. Molecular detection and identification of Brettanomyces/Dekkera bruxellensis and Brettanomyces/Dekkera anomalus in spoiled wines. Appl. Environ. Microbiol. $70,1347-1355$

Coggan, M., 2003. Ozone in wineries. Available from http://www.ciprocess.co.uk/ pdfs/Ozone_In_Wineries.pdf.

Comitini, F., Ingeniis De, J., Pepe, L., Mannazzu, I. \& Ciani, M., 2004. Pichia anomala and Kluyveromyces wickerhamii killer toxins as new tools against Dekkera/Brettanomyces spoilage yeasts. FEMS Microbiol. Lett. 238, 235-240.

Connel, L., Stender, H. \& Edwards, C.G., 2002. Rapid detection and identification of Brettanomyces from winery air samples based in peptide nucleic acid analysis. Am. J. Enol. Vitic. 53, 24-27.

Conterno, L., Joseph, C.M.L., Arvik, T.J., Henick-Kling, T. \& Bisson, L.F., 2006. Genetic and physiological characterization of Brettanomyces bruxellensis strains isolated from wines. Am. J. Enol. Vitic. 57, 139-147.

Coulter, A., Robinson, E., Cowey, G., Francis, I.L., Lattey, K., Capone, D., Gishen, M. \& Godden, P.W., 2004. Dekkera/Brettanomyces yeast - an overview of recent AWRI investigations and some recommendations for its control. In: Bell, S., de Garis, K., Dundon, C., Hamilton, R., Partridge, S. \& Wall, G. (eds). ASVO Proc. Grapegrowing at the Edge, Managing the Wine Business, Impacts on Wine Flavour, Barossa, Australia: The Australian Society of Viticulture and Oenology. pp. 51-55.

Couto, J.A., Barbosa, A. \& Hogg, T., 2005a. A simple and cultural method for the presumptive detection of the yeasts Brettanomyces/Dekkera in wines. Lett. Appl. Microbiol. 41, 505-510.

Couto, J.A., Campos, F.M., Figueiredo, A.R. \& Hogg, T., 2006. Ability of Lactic acid bacteria to produce volatile phenols. Am. J. Enol. Vitic. 57, 166-171.

Couto, J.A., Neves, F., Campos, F. \& Hogg, T., 2005b. Thermal inactivation of the wine spoilage yeasts Dekkera/Brettanomyces. Int. J. Food Microbiol. 104, 337-344.

Craig, J.T. \& Heresztyn, T., 1984. 2-Ethyl-3,4,5,6-tetrahydropyridines: An assessment of its possible contribution to the mousy off-flavor of wines. Am. J. Enol. Vitic. 35, 46-48.

Curtin, C.D., Bellon, J.R., Coulter, A.D., Cowey, G.D., Robinson, E.M.C., de Barros Lopes, M.A., Godden, P.W., Henschke P.A. \& Pretorius, I.S., 2005. The six tribes of 'Brett' in Australia - Distribution of genetically divergent Dekkera bruxellensis strains across Australian winemaking regions. Aus. Wine Ind. J. 20, 28-36.

Curtin, C.D., Bellon, J.R., Henschke, P.A., Godden, P.W. \& de Barros Lopes, M.A., 2007. Genetic diversity of Dekkera bruxellensis yeasts isolated from Australian wineries. FEMS Yeast Res. 7, 471-481.

Custers, M.T.J., 1940. Onderzoekingen over het gistgeslacht Brettanomyces. $\mathrm{PhD}$ Thesis, Delft University Delft, The Netherlands.

Davenport, R., 1976. Microflora of fruit juice products. Report of Long Ashton Research Station, Long Ashton, 136.

De Barros Lopes, M.A., Rainieri, S., Henschke, P.A. \& Langridge, P., 1999. AFLP fingerprinting for analysis of yeast genetic variation. Int. J. Syst. Bacteriol. 49, 915-924.
De Barros Lopes, M.A., Soden, A., Martens, A.L., Henschke, P.A. \& Langridge, P., 1998. Differentiation and species identification of yeasts using PCR. Int. J. Syst. Bacteriol. 48, 279-286.

Deák, T. \& Beuchat, D.R., 1995. Modified indirect conductimetric technique for detecting low populations of yeast in beverage concentrates and carbonated beverages. Food Microbiol. 12, 165-172.

Degrassi, G., Polverino de Laureto, P. \& Bruschi, C.V., 1995. Purification and characterization of ferulate and $p$-coumarate decarboxylase from Bacillus pumilus. Appl. Environ. Microbiol. 61, 326-332.

Degré, R., 1993. Selection and commercial cultivation of wine yeast and bacteria. In: Fleet, G.H. (ed). Wine Microbiology and Biotechnology, Switzerland, Harwood Academic Publishers, pp. 421-447.

Delaherche, A., Claisse, O. \& Lonvaud-Funel, A., 2004. Detection and quantification of Brettanomyces bruxellensis and 'ropy' Pediococcus damnosus strains in wine by real-time polymerase chain reaction. J. Appl. Microbiol. 97, 910-915.

Delfini, C., Gaia, P., Schellino, R., Strano, M., Pagliara, A. \& Ambro, S., 2002. Fermentability of grape must after inhibition with dimethyl dicarbonate (DMDC). J. Agric. Food Chem. 50, 5605-5611.

Dias, L., Dias, S., Sancho, T., Stender, H., Querol, A., Malfeito-Ferreira, M. \& Loureiro, V., 2003a. Identification of yeasts isolated from wine-related environments and capable of producing 4-ethylphenol. Food Microbiol. 20, 567-574.

Dias, L., Pereira da-Silva, S., Tavares, M., Malfeito-Ferreira, M. \& Loureiro, V., 2003 b. Factors affecting the production of 4-ethylphenol by the yeast Dekkera bruxellensis in enological conditions. Food Microbiol. 20, 377-384.

Drysdale, G.S. \& Fleet, G.H., 1988. Acetic acid bacteria in winemaking - a review. Am. J. Enol. Vitic. 39, 143-154.

Du Toit, M. \& Pretorius, I.S., 2000. Microbial spoilage and preservation of wine: using weapons from nature's own arsenal - a review. S. Afr. J. Enol. Vitic. 21, 74-96.

Du Toit, W.J., 2000. Sources of acetic and other fatty acids and their role in sluggish and red wine fermentations. Thesis, Stellenbosch University, Private Bag X1, 7602 Matieland (Stellenbosch), South Africa.

Du Toit, W.J., Pretorius, I.S. \& Lonvaud-Funel, A., 2005. The effect of sulphur dioxide and oxygen on the viability and culturability of a strain of Acetobacter pasteurianus and a strain of Brettanomyces bruxellensis isolated from wine. J. Appl. Microbiol. 98, 862-871.

Dugelay, I., Gunata, Z., Sapis, J.C., Baumes, R. \& Bayonove, C., 1993. Role of cinnamoyl esterase activities from enzyme preparations on the formation of volatile phenols during winemaking. J. Agric. Food Chem. 41, 2092-2096.

Edlin, D.A.N., Narbad, A., Dickinson, J.R. \& Lloyd, D., 1995. The biotransformation of simple phenolic compounds by Brettanomyces anomalus. FEMS Microbiol. Lett. $125,311-316$.

Edlin, D.A.N., Narbad, A., Gasson, M.J., Dickinson, J.R. \& Lloyd, D., 1998. Purification and characterization of hydroxycinnamate decarboxylase from Brettanomyces anomalus. Enz. Microbiol. Technol. 22, 232-239.

Egli, C.M. \& Henick-Kling, T., 2001. Identification of Brettanomyces/Dekkera species based on polymorphism in the rRNA internal transcribed spacer. Am. J. Enol. Vitic. 52, 241-247.

Eglinton, J. \& Henschke, P., 1999. The occurrence of volatile acidity in Australian wines. Austr. Grapegrow. Winemaker. Annual technical issue, 7-12.

Esteve-Zarzoso, B., Belloch, C., Uruburu, F., \& Querol, A., 1999. Identification of yeasts by RFLP analysis of the 5,8S rRNA gene and the two ribosomal internal transcriber spacers. Int. J. Syst. Bacteriol. 49, 329-337.

Esteve-Zarzoso, B., Peris-Torán, M.J., Garcia-Maiquez, E., Uruburu, F. \& Querol, A., 2001. Yeast population dynamics during the fermentation and biological ageing of sherry wines. Appl. Environ. Microbiol. 67, 2056-2061. 
Fia, G., Giovani, G. \& Rosi, I., 2005. Study of b-glucosidase production by winerelated yeasts during alcoholic fermentation. A new rapid fluorimetric method to determine enzymatic activity. J. Appl. Microbiol. 99, 509-517.

Fleet, G.H. \& Heard, G.M., 1993. Yeasts-growth during fermentation. In: Fleet, G.H. (ed). Wine Microbiology and Biotechnology. Harwood Academic Publishers, Chur, Switzerland, pp. 27-54.

Francia-Aricha, E.M., Guerra, M.T., Rivas-Gonzalo, J.C. \& Santos-Buelga, C., 1997. New anthocyanin pigments formed after condensation with flavanols. J. Agric. Food Chem. 45, 2262-2266.

Francis, I.L. \& Newton, J., 2005. Wine aroma. Aus. J. Grape Wine Res. 11, 114126.

Freer, S.N., Dien, B., \& Matsuda, S., 2003. Production of acetic acid by Dekkera/ Brettanomyces yeasts under conditions of constant pH. World J. Microbiol. Biotechnol. 19, 101-105.

Froudière, I. \& Larue, F., 1988. Condition de survie de Brettanomyces (Dekkera) dans le mout de raisin et le vin. Connaisance de la Vigne et du Vin 2, 296-303.

Fugelsang, K.C., 1997. Wine Microbiology. The Chapman \& Hall Enology Library, New York.

Fugelsang, K.C., 1998. Brettanomyces: Dr Jekyll ou Mr. Hyde des vins? Biofutur $182,22-23$.

Fugelsang, K.C., Osborn, M.M. \& Muller, C.J., 1993. Brettanomyces and Dekkera. Implications in winemaking. In: Gump, B.H. (ed). Beer and wine production: analysis, characterization and technological advances. American Chemical Society, Washington DC, pp. 110-131.

Fulcrand, H., Cameira dos Santos, P.J., Sarni-Manchado, P., Cheynier, V. \& FabreBonvin, J., 1996. Structure of new anthocyanin-derived wine pigments. J. Chem. Soc. Perkin Transactions 1, 735-739.

Gadaga, T.H., Mutukumira, A.N. \& Narvhus, J.A., 2002. Identification of yeasts isolated from Zimbabwean traditional fermented milk. Int. Diary J. 10, 459-466.

Gafner, J., 2003. Biological Stability of Wine and Biogenic Amines. In: Proc. 32 ${ }^{\text {nd }}$ Annual New York Wine Industry Workshop. pp. 74-80.

Gerbaux, V., Vincent, B. \& Bertrand, A., 2002. Influence of maceration, temperature and enzymes on the content of volatile phenols in Pinot noir wines. Am. J. Enol. Vitic. 53, 131-137.

Gilliland, R.B., 1961. Brettanomyces I. Occurrence, characteristics, and effects on beer flavour. J. Inst. Brew. 67, 257-261.

Godden, P., Coulter, A., Curtin, C., Cowey, G. \& Robinson, E., 2004. 12 ${ }^{\text {th }}$ AWITC, Brettanomyces workshop: Latest research and control strategies, Melbourne, Australia.

Gómez-Rivas, L., Escudero-Abarca, B.I., Aguilar-Uscanga, M.G., Hayward-Jones, P.M., Mendoza, P. \& Ramírez, M., 2004. Selective antimicrobial action of chitosan against spoilage yeasts in mixed culture fermentations. J. Industr. Microbiol. Biotechnol. 31, 16-22.

Granchi, L., Bosco, M., Messini, A. \& Vincenzini, M., 1999. Rapid detection and quantification of yeast species during spontaneous wine fermentation by PCR-RFL analysis of the rDNA ITS region. J. Appl. Microbiol. 97, 949-956.

Granchi, L., Romano, P., Mangani, S., Guerrini, S. \& Vincenzini, M., 2005. Production of biogenic amines by wine microorganisms. Bulletin de l'OIV, 76, 596-617.

Grbin, P.R. \& Henschke, P.A., 2000. Moussy off-flavour production in grape juice and wine by Dekkera and Brettanomyces yeasts. Austr. J. Grape Wine Res. $6,255-262$.

Grbin, P.R., 1998. Physiology and metabolism of Dekkera/Brettanomyces yeast in relation to mousy taint production. Ph.D. Thesis, The University of Adelaide, Adelaide.

Grbin, P.R., Costello, P.J., Herderich, M., Markides, A.J., Henschke, P.A. \& Lee, T.H., 1995. Developments in the sensory, chemical and microbiological basis of mousy taint in wine. In: Proc. $9^{\text {th }}$ Australian Wine Industry Technical Conference, pp. 16-19.

Guerzoni, E. \& Marchetti, R., 1987. Analysis of yeast flora associated with grape sour rot and of the chemical disease markers. Appl. Environ. Microbiol. 53, 571576 .
Guillamón, J., Sabaté, J., Cano, E.B.J. \& Querol, A., 1998. Rapid identification of wine yeast species based on RFLP analysis of the ribosomal internal transcribed spacer (ITS) region. Arch. Microbiol. 169, 387-392.

Guilloux-Benatier, M., Chassagne, D., Alexandre, H., Carpenter, C. \& Feuillat, M., 2001. Influence of yeast autolysis after alcoholic fermentation on the development of 'Brettanomyces/Dekkera' in wine. J. Int. Sci. Vigne Vin 35, 157-164.

Harwood, C.S. \& Canale-Parola, E., 1981. Branched-chain amino acid fermentation by a marine spirochete: strategy for starvation survival. J. Bacteriol. 148, 109116.

Hayashi, N., Arai, R., Tada, S., Taguchi, H. \& Ogawa, Y., 2007. Detection and identification of Brettanomyces/Dekkera sp. yeasts with a loop-mediated isothermal amplification method. Food Microbiol. 24, 778-785.

Heard, G.M. \& Fleet, G.H., 1986. Evaluation of selective media for enumeration of yeasts during wine fermentation. J. Appl. Bacteriol. 60, 477-481.

Heard, G.M. \& Fleet, G.H., 1988. The effects of temperature and pH on the growth of yeast species during the fermentation of grape juice. J. Appl. Bacteriol. $65,23-28$

Henick-Kling, T., Egli, C., Licker, J., Mitrakul, C. \& Acree, T.E., 2000. In: Proc. 5 th Int. symposium on cool climate viticulture and oenology, Melbourne, Australia, 16-20 January.

Heresztyn, T., 1986a. Metabolism of phenolic compounds from hydroxycinnamic acids by Brettanomyces yeasts. Arch. Microbiol. 146, 96-98.

Heresztyn, T., 1986b. Formation of substituted tetrahydropyridines by species of Brettanomyces and Lactobacillus isolated from mousy wines. Am. J. Enol. Vitic. 37, 127-132.

Hesford, F., Schneider, K., Porret, N.A. \& Gafner, J., 2004. Identification and analysis of 4-ethyl catechol in wine tainted by Brettanomyces off-flavor. Abstract. Am. J. Enol. Vitic. 55:304A.

Ibeas, J.I., Lozano, I., Perdigones, F. \& Jimenez, J., 1996. Detection of DekkeraBrettanomyces strains in sherry by a nested PCR method. Appl. Environ. Microbiol. 62, 998-1003.

Ison, R. \& Guttenridge, C., 1987. Determination of the carbonation tolerance of yeasts. Lett. Appl. Microbiol. 5, 11-13.

Jolly, N.P., Augustyn, O.P.H., \& Pretorius, I.S., 2003. The occurrence of nonSaccharomyces cerevisiae yeast species over three vintages in four vineyards and grape musts from production regions of the western cape, South Africa. S. Afr. J. Enol. Vitic. 24, 35-42.

Joseph, C.M.L. \& Bisson, L., 2004. Physiological diversity of Brettanomyces/ Dekkera isolated from wine. In: Technical Abstracts, 55 ${ }^{\text {th }}$ Annual Meeting, San Diego, California, Am. Soc. Enol. Vitic., Davis, CA, p. 28.

Kosse, D., Seiler, H., Amann, R., Ludwig, W. \& Scherer, S., 1997. Identification of yogurt-spoiling yeasts with $18 \mathrm{~S}$ rRNA-targeted oligonucleotide probes. Sys. Appl. Microbiol. 20, 468-480.

Kotzekidou, P., 1997. Identification of yeasts from black olives in rapid systems microtitre plates. Food Microbiol. 14, 609-616.

Krumbholz, G. \& Tauschanoff, W., 1933. Mycotorula intermedia n. sp., ein Beitrag zur Kenntnis der Gärungserreger im Wein. Zentralblatt für Bakteriologie. 88, 366-373.

Kumar, G.G. \& Anand, S.K., 1998. Significance of microbial biofilms in food industry: a review. Int. J. Food Microbiol. 42, 9-27.

Kumara, H. \& Verachtert, H., 1991. Identification of lambic superattenuating microorganisms by the use of selective antibiotics. J. Inst. Brew. 97, 181-185.

Kurtzman, C.P. \& Fell, J.W., 2000. (4 $4^{\text {th }}$ ed. revised). The yeasts. A taxonomic study. Elsevier Science Publisher BV, Amsterdam, The Netherlands.

Lachance, M.A., 1995. Yeast communities in natural tequila fermentation. Antonie van Leeuwenhoek. 68, 151-165.

Lambrechts, M.G. \& Pretorius, I.S., 2000. Yeast and its importance to wine aroma. S. Afr. J. Enol. Vitic. 21, 97-129

Laureano, P., D’Antuono, I., Barata, A., Malfeito-Ferreira, M. \& Loureiro, V., 2005. Efeito de diferentos tratamentos de sanificação na população de Dekkera bruxellensis isolada da madeira de barricas.

Lewis, K., 2001. Riddle of biofilm resistance. Antimicrob. Agents Chemother. 45, 999-1007. 
Licker, J.L., Acree, T.E. \& Henick-Kling, T., 1998. What is "Brett" (Brettanomyces) flavour? A preliminary investigation. In: Waterhouse, A.L. \& Ebeler, S.E. (eds). Chemistry of wine flavour. ACS symposium series. Am. Chem. Soc., Washington, DC, pp. 96-115.

Lonvaud-Funel, A. \& Renouf, V., 2005. Incidence microbiologique de l'usage de barriques neuves et/ou de barriques usagées. Rev. Fr. Oenol. 211, 10-14.

Lonvaud-Funel, A., 2001. Biogenic amines in wines: role of lactic acid bacteria. FEMS Microbiol. Lett. 199, 9-13.

Loureiro, V. \& Malfeito-Ferreira, M., 2003. Spoilage yeasts in the wine industry. Review. Int. J. Food Microbiol. 86, 23-50.

Loureiro, V. \& Malfeito-Ferreira, M., 2006. Dekkera/Brettanomyces spp. Chapter 13. In: Blackburn, C. de W. (ed). Food spoilage microorganisms. Woodhead Publishing Ltd, Abington, Cambridge, UK. pp. 353-398.

Loureiro, V. \& Querol, A., 1999. The prevalence and control of spoilage yeasts in foods and beverages. Trends Food Sci. Technol. 10-11, 356-365.

Loureiro, V., 1997. Spoilage yeast in food and beverages. Final scientific report of the European AIR project CT93/830. DGXII-E-2, Bruxelles.

Loureiro, V., 2000. Spoilage yeasts in food and beverages: characterisation and ecology for improved diagnosis and control. Food Res. Int. 33, 247-256.

Malfeito-Ferreira, M., Barata, A., Nobre, A., Tavares, M., Dias, L., Pereira-da-Silva, S., Gonçalves, G., Rodrigues, N. \& Loureiro, V., 2004. "Behavior of Brettanomyces bruxellensis and Pichia guilliermondii in wines". In: Proc. Brettanomyces seminar presented at ASEV 55th Annual Meeting, San Diego, California, p. 31.

Malherbe, S., Bauer, F.F. \& Du Toit, M., 2007. Understanding Problem Fermentations - A Review. S. Afr. J. Enol. Vitic. 28, 169-186.

Mansfield, A.K., Zoecklein, B.W. \& Whiton, R.S., 2002. Quantification of glycosidase activity in selected strains of Brettanomyces bruxellensis and Oenococcus oeni. Am. J. Enol. Vitic. 53, 303-307.

Margalit, Y., 1997. Concepts in wine chemistry. The Wine Appreciation Guild Ltd, South San Francisco, California, USA.

Martorell, P., Barata, A., Malfeito-Ferreira, M., Fernandez-Espinar, M.T., Loureiro, V. \& Querol, A., 2006. Molecular typing of the yeast species Dekkera bruxellensis and Pichia guilliermondii recovered from wine related sources. Int. J. Food Microbiol. 106, 79-84.

McMahon, H., Zoecklein, B.W., Fugelsang, K. \& Jasinski, Y., 1999. Quantification of glycosidase activities in selected yeasts and lactic acid bacteria. J. Ind. Microbiol. Biotechnol. 23, 198-203.

Millet, V. \& Lonvaud-Funel, A., 2000. The viable but non-culturable state of wine micro-organisms during storage. Lett. Appl. Microbiol. 30, 136-141.

Miot-Sertier, C. \& Lonvaud-Funel, A., 2007. Development of a molecular method for the typing of Brettanomyces bruxellensis (Dekkera bruxellensis) at the strain level. J. Appl. Microbiol. 102, 555-562.

Mitrakul, C.M., Henick-Kling, T. \& Egli, C.M., 1999. Discrimination of Brettanomyces/Dekkera yeasts from various DNA finger-printing methods. Food Microbiol. 16, 3-14.

Mok, C., Song, K.T., Park, Y.S., Lim, S., Ruan, R. \& Chen, P., 2006. High hydrostatic pressure pasteurization of red wine. J. Food Sci. 71, 265-269.

Morata, A., González, C. \& Suárez-Lepe, J.A., 2007. Formation of vinylphenolic pyranoanthocyanins by selected yeasts fermenting red grape musts supplemented with hydroxycinnamic acids. Int. J. Food Microbiol. 116, 144-152.

Murat, M.L. \& Dumeau, F., 2003. Impact of fining on population levels of certain spoilage micro-organisms in red wines. Austr. New Zealand Grapegrow. Winemaker, 478, 92-94.

Nelson, L., 2008. Investigating the influence of lactic acid bacteria and Saccharomyces cerevisiae on the production of volatile phenols by Brettanomyces. MSc Thesis, Stellenbosch University, South Africa.

Nisiotou, A.A. \& Gibson, G.R., 2005. Isolation of culturable yeasts from market wines and evaluation of the 5.8S-ITS rDNA sequence analysis for identification purposes. Lett. Appl. Microbiol. 41, 454-464.

Oelofse, A. \& Du Toit, M., 2006. Brettanomyces/Dekkera during winemaking (Part 2). What the winemaker could do. Wineland 199, 66-67.

Oliver, J.D., 1993. Formation of viable but nonculturable cells. In: Kjelleberg, S. (ed). Starvation in Bacteria. Plenum Press, New York. pp. 239-271.
Oliver, J.D., Hite, F., McDougald, D., Andon, M.L. \& Simpson, L.M., 1995. Entry into and resuscitation from the viable but non culturable state by Vibrio vulnificus in an estuarine environment. Appl. Environ. Microbiol. 61, 2624-2630.

Olsen, E., 1994. Brettanomyces: occurrence, flavour effects and control. The Cornell University Agricultural Research Station at Geneva NY. (N.Y.S.A.E.S.). $23^{\text {rd }}$ Annual New York Wine Industry Workshop.

Ough, C.S., 1983. Dimethyl dicarbonate and diethyl dicarbonate. In: Branen, A.L. \& Davidson, P.M. (eds). Antimicrobials in foods. New York/Basel: Marcel Dekker, pp. 299-325.

Phaff, H.J., Miller, M.W. \& Mrak, E.M. 1978 ( $2^{\text {nd }}$ ed). The Life of Yeasts. Harvard University Press, Cambridge, MA, p. 341.

Phister, T.G. \& Mills, D.A., 2003. Real-Time PCR assay for the detection and enumeration of Dekkera bruxellensis in wine. Appl. Environ. Microbiol. 69, 7430-7434.

Pollnitz, A.P., Pardon, K.H. \& Sefton, M.A., 2000. 4-Ethylphenol, 4-ethylguaiacol and oak lactones in Australian red wines. Aus. Grapegrow. Winemaker 438, 4552.

Potgieter, N., 2004. The evaluation of b-glucosidase activity produced by wine isolated yeasts. MSc Thesis, Stellenbosch University, South Africa.

Prakitchaiwattana, C., Fleet, G.H. \& Heard, G.M., 2004. Application and evaluation of denaturing gradient gel electrophoresis to analyse the yeast ecology of wine grapes. FEMS Yeast Res. 4, 865-877.

Pretorius, I.S., 2000. Tailoring wine yeast for the new millennium: novel approaches to the ancient art of winemaking. Yeast 16, 675-729.

Puig, A., Vilavella, M., Daoudi, L., Guamis, B. \& Minguez, S., 2003. Microbiological and biochemical stabilization of wines by application of high pressure processing. Bull. de l'OIV, 76, 596-617.

Querol, A., Jiménez, M. \& Huerta, T., 1990. Microbiological and enological parameters during fermentation of musts from poor and normal grape harvests in the region of Alicante, Spain. J. Food Sci. 55, 1603-1606.

Quintas, C., Leyva, J.S., Sotoca, R., Loureiro-Dias, M.C. \& Peinado, J.M., 2005. A model of the specific growth rate inhibition by weak acids in yeasts based on energy requirements. Int. J. Food Microbiol. 100, 125-130.

Redzepovic, S., Orlic, S., Sikora, S., Majdak, A. \& Pretorious, I.S., 2002. Identification and characterization of Saccharomyces cerevisiae and Saccharomyces paradoxus strains isolated from Croatian vineyards. Lett. Appl. Microbiol. 35, 1-6.

Renouf, V. \& Lonvaud-Funel, A., 2006. Development of an enrichment medium to detect Dekkera/Brettanomyces bruxellensis, a spoilage wine yeast, on the surface of grape berries. Microbiol. Res. 162, 154-167.

Renouf, V., Falcou, M., Miot-Sertier, C., Perello, M.C., De Revel G. \& LonvaudFunel, A., 2006a. Interactions between Brettanomyces bruxellensis and other yeast species during the initial stages of winemaking. J. Appl. Microbiol. 100, 1208-1219.

Renouf, V., Miot-Sertier, C., Strehaiano, P. \& Lonvaud-Funel, A., 2006c. The wine microbial consortium: a real terroir characteristic. J. Int. Sci. Vigne Vin 40, 209-216.

Renouf, V., Perello, M.C., Strehaiano, P. \& Lonvaud-Funel, A., 2006b. Global survey of the microbial ecosystem during alcoholic fermentation in winemaking. J. Int. Sci. Vigne Vin 40, 101-106.

Renouf, V., Strehaiano, P. \& Lonvaud-Funel, A., 2007. Effectiveness of dimethlydicarbonate to prevent Brettanomyces bruxellensis growth in wine. Food Control 19, 208-216..

Ribéreau-Gayon, P., Dubourdieu, D., Donéche, B. \& Lonvaud, A., 2000. The use of sulfur dioxide in must and wine treatments. In: Ribéreau-Gayon, P. (ed). Handbook of Enology Vol. 1. The Microbiology of Winemaking. Chichester, UK: John Wiley \& Sons Ltd, pp. 179-205

Röder, R., König, H., \& Fröhlich, J., 2007. Species-specific identification of Dekkera/Brettanomyces yeasts by fluorescently labeled DNA probes targeting the 26S rRNA, FEMS Yeast Res. 7, 1013-1026.

Rodrigues, N., Gonçalves, G., Pereira-da-Silva, S., Malfeito-Ferreira, M. \& Loureiro, V., 2001. Development and use of a new medium to detect yeast of the genera Dekkera/Brettanomyces sp. J. Appl. Microbiol. 90, 588-599. 
Romano, P. \& Suzzi, G., 1992. Sulfur dioxide and wine microorganisms. In: Fleet, G.H. (ed). Wine technology and Biotechnology. Harwood, Academic Publishers, Chur, Suisse, pp. 373-393.

Ruiz-Hernández, M., 2003. Casein for correction of defects caused by Brettanomyces and Dekkera. Semana Vitivinícola 58, 1462-1463.

Scheffers, W.A. \& Wiken, T.O., 1969. The Custer effect (negative Pasteur effect) as a diagnostic criterion for the genus Brettanomyces. Anton. Leeuw. Supplement: Yeast Symposium 35, 31-32.

Schwarz, M., Wabnitz, T.C. \& Winterhalter, P., 2003. Pathway leading to the formation of anthocyanin-vinylphenol adducts and related pigments in red wines. J. Agric. Food Chem. 51, 3682-3687.

Shinohara, T., Kubodera, S. \& Yanagida, F., 2000. Distribution of phenolic offflavours in wine fermentation. J. Biosci. Bioeng. 90, 90-97.

Simon-Sarkadi, L. \& Holzapfel, W.H., 1994. Determination of biogenic amines in leafy vegetables by aminoacid analyser. Z. Lebensm. Unters. For. 198, 230-233.

Smith, C.R., 1996. Studies of sulfur dioxide toxicity for two wine yeasts. University of California, Davis.

Smith, M.T., 1998. Dekkera van der Walt. Chapter 27. In: Kurtzman, C.P. \& Fell, J.W. (eds). The yeasts: A taxonomic study. Elsevier, Amsterdam, the Netherlands, pp. 174-177.

Snowdon, M.E., Bowyer, M.C., Grbin, P.R. \& Bowyer, P.K., 2006. Mousy offflavour: A review. J. Agric. Food Chem. 54, 6465-6474.

Somers, T.C. \& Verette, E., 1988. Phenolic composition of natural wine types. In: Linskens, H.F. \& Jackson, J.F. (eds). Modern methods of plant analysis. New series. Vol 6. Wine analysis. Springer-Verlag, Berlin, pp. 219-257.

Stead, D., 1995. The effect of hydroxycinnamic acids and potassium sorbate on the growth of 11 strains of spoilage yeasts. J. Appl. Bacteriol. 78, 82-87.

Stender, H., Kurtzman, C., Hyldig-Nielsen, J.J., Sorensen, D., Broomer, A., Oliveira, K., Perry-O'Keefe, H., Sage, A., Young, B. \& Coull, J., 2001. Identification of Dekkera bruxellensis (Brettanomyces) from wine by fluorescence in situ hybridization using peptide nucleic acid probes. Appl. Environ. Microbiol. 67, 938-941.

Stratton, J.E., Hutkins, R.W. \& Taylor, S.L., 1991. Biogenic amines in cheese and other fermented foods: a review. J. Food Protect. 54, 460-470.

Suárez, R., Suárez-Lepe, J.A., Morata, A. \& Calderón, F., 2007. The production of ethylphenols in wine by yeasts of the genera Brettanomyces and Dekkera: A review. Food Chem. 102, 10-21.

Swaffield, C.H. \& Scott, J.A., 1995. Existence and development of natural microbial populations in wooden storage vats used for alcoholic cider maturation. J. Am. Soc. Brew. Chem.53, 117-120.

Swaffield, C.H., Scott, J.A. \& Jarvis, B., 1997. Observations on the microbial ecology of traditional alcoholic cider storage vats. Food Microbiol. 14, 353-361.

Taillandier, P., 2007. Humidité et azote, des facteurs aggravants. La Vigne. No. 189 de Juillet-Aout, p. 50.

Teoh, A.L., Heard, G. \& Cox, J., 2004. Yeast ecology of Kombucha fermentation. Int. J. Food Microbiol. 95, 119-126.

Teranashi, R., Buttery, R.G. \& Guadagni, D.G., 1975. Odor, thresholds, and molecular structure. In: Drawert, F. (ed). Gerunch und Geschmackstoffe; Verlag Nurnberg, Germany, pp. 177-186.
Threlfall, R.T. \& Morris, J.R., 2002. Using dimethyldicarbonate to minimize sulfur dioxide for prevention of fermentation from excessive yeast contamination on juice and semi-sweet wine. J. Food Sci. 67, 2752-2758

Ugarte, P., Agosin, E., Bordeu, E. \& Villalobos, J.I., 2005. Reduction of 4-ethylphenol and 4-ethylguaiacol concentration in red wines using reverse osmosis and adsorption. Am. J. Enol. Vitic. 56, 30-36.

Van Beek, S. \& Priest, F.G., 2000. Decarboxylation of substituted cinnamic acids by lactic acid bacteria isolated during malt whisky fermentation. Appl. Environ. Microbiol. 66, 5322-5328.

Van de Water, L., 2004. Dekkera/Brettanomyces. Technical seminar. Presented at the $12^{\text {th }}$ Aust.Wine Ind. Tech. Conf., July 2004, Melbourne, Australia.

Van der Walt, J.P. \& Van Kerken, A.E., 1958. The wine yeast of the Cape. Part I. A taxonomical survey of the yeasts causing turbidity in South African table wines. Antonie van Leeuwenhoek. 24, 239-252.

Van der Walt, J.P. \& Van Kerken, A.E., 1960. The wine yeasts of the Cape. Part IV. Ascospore formation in the genus Brettanomyces schanderlii. Antonie van Leeuwenhoek. 26, 291-296.

Van der Walt, J.P. \& Van Kerken, A.E., 1961. The wine yeasts of the Cape. Part V. Studies on the occurence of Brettanomyces schanderlii. Antonie van Leeuwenhoek. 27, 81-90

Van der Walt, J.P., 1984. Dekkera van der Walt. In: Kreger-van Rij, N.J.W. (ed). The Yeasts: A Taxonomic Study. Elsevier Science Publishers, Amsterdam, The Netherlands, pp. 146-150.

Van der Westhuizen, T., Augustyn, O., Khan, W. \& Pretorius, I.S., 2000. Geographical distribution of indigenous Saccharomyces cerevisiae strains from vineyard in the coastal regional of the Western Cape in South Africa. S. Afr. J. Enol. Vitic. 21, 3-9.

Van Wyk, C.J. \& Rogers, I.M., 2000. A “phenolic" off-odour in white table wines: causes and methods to diminish its occurrence. S. Afr. J. Enol. Vitic. 21, 52-57.

Van Zyl, J.A., 1962. Turbidity in South African dry wines caused by the development of the Brettanomyces yeasts, Science Bulletin No. 381, Viticultural and Enological Research Institute, Stellenbosch, South Africa.

White, T.J., Bruns, T., Lee, S. \& Taylor, J., 1990. Amplification and direct sequencing of fungal ribosomal RNA genes for phylogenetics. In: Innis, M.A., Gelfand, D.H., Sninsky, J.J \& White, T.J. (eds). PCR Protocols, A Guide to Methods and Applications. Academic Press, San Diego, California, pp. 315-322.

Wijsman, M.R., Van Dijken, J.P., Van Kleef, B. \& Scheffers, A., 1984. Inhibition of fermentation and growth in batch cultures of the yeast Brettanomyces intermedius upon a shift from aerobic to anaerobic conditions (Custers effect). Anton. Leeuw. 50, 183-192.

Woolfit, M., Rozpedowska, E., Piskur, J. \& Wolfe, K.H., 2007. Genome survey sequencing of the wine spoilage yeast Dekkera (Brettanomyces) bruxellensis. Eukaryot. Cell 4, 721-733.

Wright, J.M. \& Parle, J.N., 1974. Brettanomyces in the New Zealand wine industry. New Zealand. J. Agric. Res. 17, 273-278.

Yap, A., Jiranek, V., Grbin, P., Barnes, M. \& Bates, D., 2007. Studies on the application of high-power ultrasonics for barrel and plank cleaning and disinfection. Aus. Wine Ind. J. 22, 96-104.

Zaldivar, J. \& Ingrim, L.O., 1999. Effect of organic acids on the growth and fermentation of ethanologenic Escherichia coli LY01. Biotech. Bioeng. 66, 203210 . 